\title{
LOS GUATEMALTECOS DE 1770 EN LA DESCRIPCIÓN DE PEDRO CORTÉS Y LARRAZ
}

\author{
José Aumjos Garcta ${ }^{1}$ \\ CEM, IIF, UNAM
}

"Estas son cosas que solamente se saben entrando como he entrado en los jacales..."

\section{Introducción}

Recorrer la Guatemala de 1770 a través de la Descripcion ${ }^{2}$ del arzobispo Cortés y Larraz es intemarse en el corazón mismo del país y de su gente, es una manera de observar por dentro a la sociedad de la época. El carácter de esta obra permite acercarse al pensamiento de su autor, al de un extraordinario personaje religioso de la historia patria. A la vez, analizando la visión del mundo y de la vida, las ideas y valores de este ilustre prelado, y contrastándolos con la realidad por él descrita, es posible entender mejor el pasado histórico y la problemática contemporánea.

${ }^{1}$ Este artículo es producto de un estudio antropológico sobre Guatemala que realizo en el Centro de Estudios Mayas de la UNAM. Agradezco los valiosos comentarios y críticas de mis colegas Tatiana Bubnova, Gudrun Lenkersdorf, Carmen Loon, Elsa Ortega y Mario Ruz.

${ }^{2}$ Pedro Cortés y Larraz, Descripción geográfico-moral de la Diócesis de Goathemala, Guatemala, Sociedad de Geografia e Historia, Biblioteca "Goathemala", vol. XX, 1958, 2 tomos. En las citas a esta obra, entre paréntesis se indica primero el número del tomo (I o II) seguido del número de la página. En ocasiones se obvia esta referencia pues al dar el nombre del pueblo, es fácil su localización en el findice general del libro. 
Un proposito de mi trabajo es rescatar dicha obra como una fuente original, de primera mano y de gran valor para el estudio de la sociedad guatemalteca. Trato de hacer un analisis y una interpretación de su contenido etnologico, es decir que busco en la obra información sobre la composición cultural y el sistema de diferenciación social existentes, asf como sobre el carácter de las relaciones entre las distintas "etnias". ${ }^{3}$

Muchos investigadores han recurrido a esta fuente en busca de algún dato especffico, pero casi nadie se ha detenido para estudiarla como una totalidad, como un objeto de investigación en sf misma. De hecho, resulta asombroso el poco interés que se ha puesto a esta original y valiosa fuente documental. ${ }^{4}$ Pocos son los historiadores que la han consultado en profundidad para interpretar la realidad colonial guatemalteca de aquel entonces. ${ }^{5}$

Mi propio trabajo debe considerarse como un intento por recuperar algo de lo mucho que contiene la obra, como una selección de la información orientada por un interés antropologico sobre la sociedad guatemalteca. En ese sentido, es una fortuna contar con el propio interes del prelado, quien desde un inicio advierte que el objeto de su trabajo es "lo moral y eclesiástico" y que como resultado del mismo, había llegado a "entender a fondo y a comprender los pensamientos, palabras y obras de todas estas gentes" (I,61). bajo.

${ }^{3}$ Véase la discusión sobre el término etnia, en las conclusiones de este tra-

4 Cf. Murdo Macleod Relaciones étnicas y la sociedad indigena en la Provincia de Guatemala, ca. 1620-ca. 1800, Guatemala, SISG, 1987. El autor ignora la riqueza de la obra de Cortés y Larraz, clasifićandola dentro de la tradición "macrosc6pica" de los grandes cronistas coloniales, orientada según 61 , "hacia los eventos políticos y hacia la historia social, cultural y economica de las élites civiles y clericales y de los gobiernos" (p. 8). Aqui, Macleod cae en un error de generalización que él mismo intenta criticar.

5 Jesús Garcia Añoveros Población y estado sociorreligiaso de la diocesis de Guatemala en el áltimo tercio del siglo XVIII, Guatemala, USAC, Editorial Universitaria, 1987; Severo Martínez Pelíez, La patria del criollo, Guatemala, Editorial Universitaria, 1970. 


\section{El prelado}

Pedro Cortés y Larraz (1712-1787) ${ }^{6}$ fue un aragonés nacido en Belchite, provincia de Zaragoza, España, quien en virtud de sus méritos fue nombrado arzobispo de la dícesis de Guatemala por el rey Carlos III, país al que llego en febrero de 1768. A lo largo de su administración, que duro hasta 1779 , lo distinguio su interés y preocupación por Guatemala, evidente desde un inicio en su decisión de conocer personalmente toda la diócesis, y más adelante, en su tenaz lucha por reconstruir la infortunada ciudad capital de Santiago, destruida con el terremoto de Santa Marta, el 29 de julio de 1773 . Ante esa tragedia, el arzobispo luchó con toda energia por salvar a la ciudad de la ruina y el abandono, ayudando a sus vecinos a recuperarse $\mathrm{e}$ iniciar la reconstrucción, negándose a trasladar la sede del arzobispado al Valle de La Ermita, donde se fundarfa la nueva ciudad, según disposiciones del gobiemo civil. Hasta su retiro definitivo de Guatemala, él se opuso a tal decisión, siendo esa la causa de los conflictos que al final determinaron su retomo a Europa.

Fue este un eclesiástico comprometido con sus creencias y su fe en el cristianismo de su iglesia; convencido de que la única salvación posible estaba en la religión, que para la superación real de los enormes problemas sociales de Guatemala era indispensable una profunda conversión al verdadero cristianismo, ese que él profesó. Es por eso que sus juicios sobre la sociedad son tan radicales, $\tan$ criticos y severos, porque su rebaffo estaba perdido y era necesario que encontrara el buen camino. Eso mismo lo hace un gran humanista, un sincero amigo del pais, porque su visión unida a sus acciones, expresan una genuina preocupación por la felicidad de su gente.

En el libro se encuentran varias muestras de su humanismo, que solfan chocar con la indiferencia y crueldad de sus congéne-

6 Sobre su vida y obra, véase la introducción de Recinos en el tomo I de este libro, y en García Affoveros (1987). 
res, pero también con la mentalidad indígena. Un ejemplo de esto último fue su intento frustrado de recoger nifos indigenas para educarlos. Es claro que una de las mayores preocupaciones del arzobispo fueron las condiciones de vida de los indios y por ello busco soluciones para sus más graves problemas. Ello quedó expresado en un gesto muy significativo: a su muerte en Zaragoza, el prelado lego su cuantiosa renta para la fundación de un colegio en Guatemala que se ocupara de instruir a la juventud. Sin embargo, al parecer la Corona no cumplió con aquel último deseo, remitiendo el dinero a Espaffa, por considerar "inoficioso el establecimiento".

Cortés fue también un intelectual con una gran curiosidad y una mente inquisitiva, muy influenciado por la Ilustración, con un enorme afán por conocer los origenes de los hechos sociales que encontraba a cada paso en Guatemala. Al parecer, estaba familiarizado con las crónicas, informes y demás documentación sobre la diócesis. Los métodos empleados en su trabajo "en el terreno" y en la redacción del informe al rey muestran la calidad de sus méritos intelectuales. Además, como todo un ilustrado y alto funcionario del sistema colonial, al obispo le preocupo el atraso económico del pafs y la mala administración del Reino, buscando soluciones, con una visión positiva y práctica. En varios lugares de su informe se le ve tratar con atención determinada problemática, analizarla en sus componentes principales, para luego argumentar propuestas viables y de beneficio para la sociedad y para la Corona. De alli su idea de convertir los trapiches en ingenios de azúcar para aumentar la productividad y por tanto los ingresos a la Real Hacienda y acabar al mismo tiempo con el vicio del aguardiente. Lo mismo ocurre con sus consideraciones sobre el potencial económico de las salinas de la Costa Sur.

Por otro lado, en cierto nivel político-cultural, la figura del arzobispo también muestra cómo se ejerció el dominio espanol en el pars. Asf, la imposición de la religión y moral católicas, y de la cultura hispana en general, fue un procedimiento generalizado para consolidar ideologicamente al sistema colonial. 


\section{La Descripción}

La Visita ${ }^{7}$ que realiza Cortés y Larraz es comparable a la de un etnógrafo que registra lo que observa, contrastándolo y comparándolo con su propia visión del mundo. Por supuesto, la intención de sus escritos no fue servir como fuente histórica o antropológica, sino que simplemente realizaba un informe confidencial y objetivo, destinado al rey, para hacer de su conocimiento el verdadero estado de la diocesis. Ya desde las primeras páginas seffala cómo "se encuentran estos Reinos en estado bien deplorable, inundados en todo género de vicios, abismados en toda especie de iniquidades y puestos en tanto desorden"; le preocupa la mentira y falsedad en los informes sobre la diócesis que los funcionarios civiles y eclesiásticos envían a España. Según él, las respuestas de los párrocos a su cuestionario fueron, "en unas el artificio, en otras el engaffo y en todas el disimulo" (I,12). De all que su proposito sea dar una descripción veraz y completa al rey, para que éste pueda tomar medidas efectivas en la solución de los graves problemas descubiertos.

Es manifiesta su gran preocupación por conocer a fondo la diocesis que debfa administrar, la moral de sus habitantes, su economía, geografia y riquezas naturales. De alli que tan pronto se hubo instalado en Goathemala, envio una carta pastoral a todos los curatos de su jurisdicción, solicitando información especffica sobre cada parroquia, ${ }^{8}$ contenida en un cuestionario que los curas debfan

7 Visitas periódicas a los poblados de la dícesis eran una de las obligaciones de los obispos. Así también era rutinario el efectuar cuestionarios similares al realizado por Cortés. El mérito de su trabajo consiste en la contrastación que hace entre las respuestas dadas por los curas y sus propias observaciones.

8 El cuestionario de la carta pastoral comprendía los siguientes asuntos: 1) cuál es la renta del curato y a cuánto asciende; 2) los idiomas hablados en la parroquia y si existe alguien "ordenado a este título", experto en ellas; 3 ) lista de todos los poblados y las distancias entre ellos; 4) lista de familias y su composición por poblado; 5) vicios, escíndalos, abusos y sus remedios; 6) cumplimiento de los deberes religiosos católicos y civiles; 7) educación: escuelas, maestros, alumnos; 8) idolatrías y supersticiones; 9) libros empleados para la explicación de la doctrina; y 10) castigos y vejaciones a los indios (I, 15 16). 
responder por escrito y entregárselo cuando él pasara de visita a las parroquias. Fue asf que Cortés inicio un viaje de cerca de dos años de duración a los 113 curatos de la diócesis, ${ }^{9}$ con sólo dos cortos descansos, abarcando desde el extremo oriental de Chiapas hasta el Golfo de Fonseca y desde la Costa Sur guatemalteca hasta la zona limítrofe con el actual Departamento de El Petén.

La visita la inició el 3 de noviembre de 1768 a la edad de 55 affos, saliendo de la ciudad de Santiago hacia el sur-oriente, pasando por la totalidad de los curatos de El Salvador, luego recorrio las verapaces, El Quiché y Chimaltenango, para volver a la capital ocho meses más tarde. El 22 de noviembre del siguiente affo continuó por cerca de tres meses en la región montaffosa central y occidental, conocida como el altiplano y por último, del 6 de junio de 1770 al 29 de agosto del mismo afio recorrio la Costa Sur para concluir su tarea.

Para entender la magnitud de tal empresa hay que considerar las dificultades extremas que el arzobispo enfrento al viajar por el país en aquella época. A los precarios medios de transporte, que en muchas ocasiones significaba dejar la mula para tratar de salvar los obstáculos a pie, estaban los caminos escabrosos y accidentados, "violentos" como él los llama, propios de aquella accidentada geografia. Aparte, hay que sumar las dificultades encontradas en los poblados aldeanos habitados por indígenas monolingües, a veces poco dispuestos a obedecer las disposiciones del obispo. Como le sucedió en más de una ocasión, una orden suya que afectara los intereses indigenas podía provocar reacciones adversas, como el dejarlo abandonado a su suerte, en un pueblo deshabitado, agreste y desconocido.

Las preguntas contenidas en el cuestionario enviado a los curas manifiestan los intereses y preocupaciones fundamentales de Cortés, al grado de que las mismas son la principal gura de sus observaciones en el terreno y de su obra escrita. En la descripción de

\footnotetext{
9 Véase el mapa adjunto para esta y las posteriores referencias a los pueblos visitados.
} 


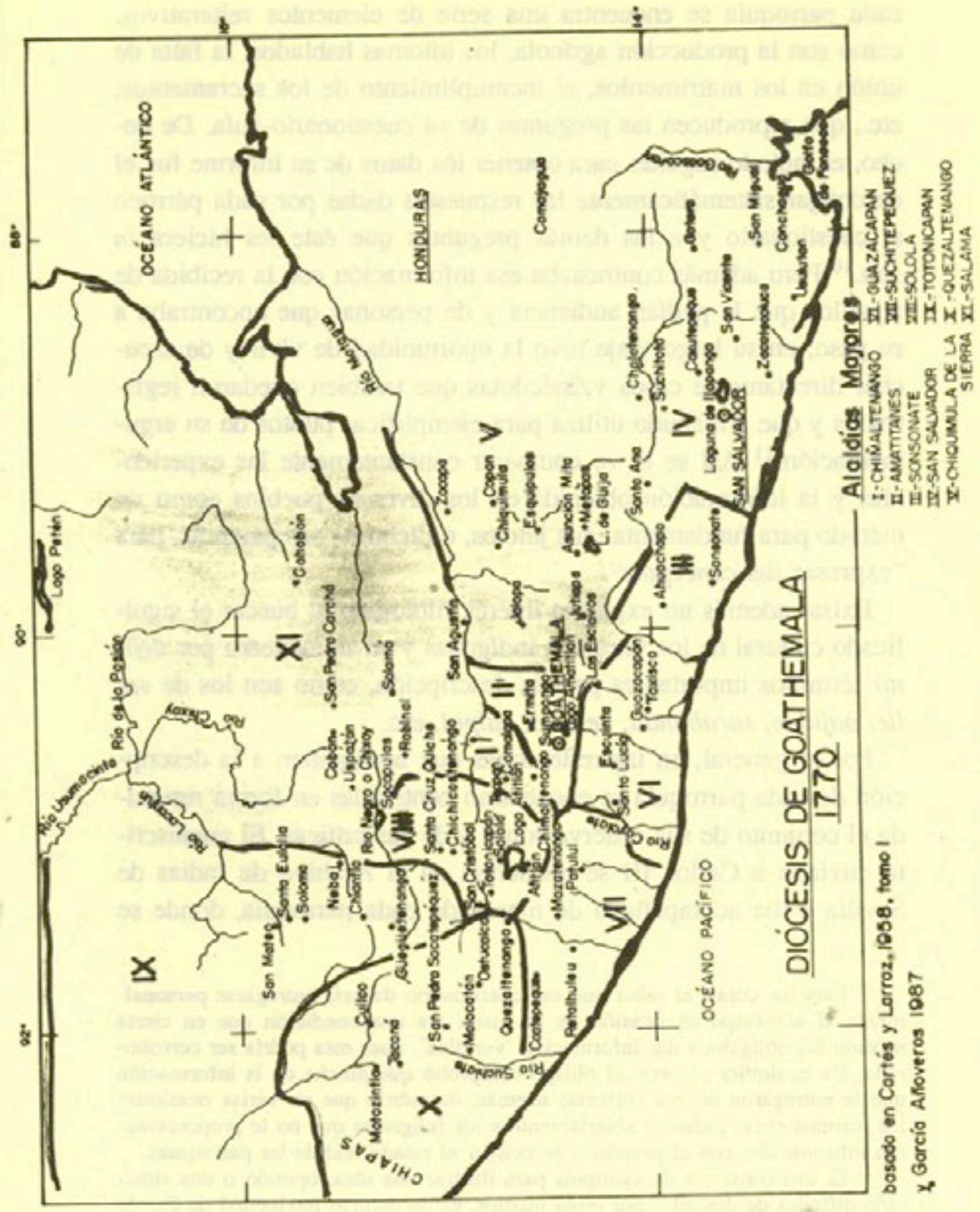


cada parroquia se encuentra una serie de elementos reiterativos, como son la producción agrícola, los idiomas hablados, la falta de unión en los matrimonios, el incumplimiento de los sacramentos, etc., que reproducen las preguntas de su cuestionario-gufa. De hecho, el método seguido para obtener los datos de su informe fue el de cotejar sistemáticamente las respuestas dadas por cada párroco al cuestionario y a las demás preguntas que éste les hiciera in situ. ${ }^{10}$ Pero además contrastaba esa información con la recibida de aquellos que le pedian audiencia y de personas que encontraba a su paso; en su largo viaje tuvo la oportunidad de vivir y de escuchar directamente casos y anécdotas que también quedaron registrados y que a menudo utiliza para ejemplificar puntos de su argumentacion. ${ }^{11}$ Así se le ve comparar constantemente las experiencias y la información obtenida en los diversos pueblos como un método para fundamentar sus juicios, o dicho en sus palabras, para "expresar sus conceptos".

Existe además un explícito interés filologico al buscar el significado cultural de los vocablos indígenas y en su esfuerzo por definir términos importantes para la descripción, como son los de valle, pajuide, sarabanda, velorio, calpul, etc.

Por lo general, en las reflexiones que acompanan a la descripción de cada parroquia se encuentran contenidas en forma resumida el conjunto de sus observaciones y de sus criticas. El manuscrito enviado a Carlos III se encuentra en el Archivo de Indias de Sevilla e iba acompañado de mapas de cada parroquia, donde se

${ }^{10}$ Para los curas, el saber que ese cuestionario debería entregarse personalmente al arzobispo en ocasión de su visita era una condición que en cierta medida los obligaba a dar información 'verídica', pues esta podría ser corroborada. De cualquier manera, el obispo comprob6 que mucha de la información que le entregaron no era correcta; además, descubrí que en varias ocasiones los mismos curas pidieron abiertamente a los feligreses que no le proporcionaran información, con el propósito de ocultar el estado real de las parroquias.

${ }^{11}$ El uso constante de ejemplos para ilustrar una idea, opinión o una situación dificiles de describir por otros medios, es un recurso intelectual de Cort'́s muy afortunado para la investigación antropologica, por el contenido cultural expresado en dichos ejemplos. En este trabajo reproduzco algunos de estos casos, como él los llama. Cf. las reflexiones sobre la parroquia de Matzahuat. 
muestra con bastante precisión el paisaje natural, la disposición y trazo de los principales poblados y los accidentes geográficos más sobresalientes. Aunque en el prólogo el autor afirma carecer de conocimientos de geografia, la información que proporciona al respecto es interesante, pues al compararla con las actuales condiciones del territorio considerado, pueden verse los grandes cambios ocurridos a todo nivel, particularmente en la agricultura, en los "caudales de agua" y en el grave deterioro ecológico.

\section{Dominio hispano}

La Visión del arzobispo. Es evidente que existe una fuerte carga religiosa que influye en los juicios y criticas del arzobispo respecto a la sociedad guatemalteca. En cierta medida, su pensamiento religioso actúa como una ideología con la cual construye la realidad social que describe. ${ }^{12}$ Sin embargo, ello no debe tomarse $a$ priori como una "deformación" de la realidad, que invalide la Descripción. Primero es indispensable observar en qué consiste, dónde y en qué sentidos ocurre esa interferencia ideologico-cultural, para asi distinguir lo objetivo de lo valorativo. Por otro lado, ese mismo sesgo constituye en sf mismo una rica fuente de información sobre el modelo cognitivo de Cortes, y a un nivel abstracto, a veces por oposición, también refleja el modelo de los espanfoles. Asf pues, es necesario reconocer en la obra distintos niveles de información factual, 'etnográfica'.

Es claro que la visión de Cortés no la comparten la mayoría de sus congéneres. La suya es la del funcionario religioso ilustrado, culto y preocupado por su diócesis. En él no se trata, como sf́ en otros funcionarios españoles, de un uso ideológico de la moral religiosa por intereses económicos y politicos, sino más bien de una genuina concepción religiosa del mundo y de la vida. Juzga a

12 A veces, su religiosidad lo hace explicar hechos naturales como productos de la intervención divina. Así, "el diluvio o inundación" sufridos en Chiquimula, Petapa, Atheos y otros pueblos, lo considera castigo a los pecados de la gente, por "hallarse Dios ofendido" (I,276). 
los españoles en base a una regla compartida, puesto que ambos creen en la misma religión y con ella los mide, es decir, en la medida en que conducen sus vidas de acuerdo a los preceptos cristianos. Pero luego también juzga a los ladinos y a los indios con la misma regla, como si estos compartieran su misma norma cultural de conducta. Lo que descubre una y otra vez, es que en el fondo ellos no son cristianos, aunque aparenten serlo. Asf lo afirma en una de sus reflexiones: "Yo venfa desde que pisé la América con bastante recelo sobre la religion de los indios, hallando fundamentos para más y más dudar a cada paso" (II,184).

Puestos los espaffoles de la diócesis en la escala moral del prelado, el extremo más alto lo constituye su propio ideal humano, mientras que en el otro extremo están los espafioles degenerados, aquellos que viven en el monte, amancebados con los indios y los ladinos. Arriba están los españoles "decentes", los verdaderos católicos (principalmente los peninsulares), los vecinos honorables de las ciudades, que son un grupo muy pequeño y los curas de las parroquias, aunque a muchos de ellos los encuentra corruptos. Por el otro lado están los españoles que viven en el campo (los criollos), los administradores públicos, los duefios de las haciendas, los comerciantes y los artesanos, que son probablemente el grupo más numeroso. Cada uno de estos grupos constitufan por asi decirlo, variantes de la concepción moral católica. Los que viven en el campo, según el prelado, son quienes caen con más facilidad en la inmoralidad, en el vicio y la corrupción.

Es frecuente encontrar en la Descripción juicios sobre la calidad espiritual, sobre el estado moral de los habitantes, según el modelo de la moral cristiana que el prelado representa. Destacan como constantes entre sus observaciones 1) el paganismo, las idolatrias y las creencias prehispánicas, 2) la desnudez, y con ella la lujuria, la promiscuidad, el amancebamiento y el incesto, 3) la embriaguez, producto de la fabricación y el comercio incontrolados de aguardiente, y 4) la dispersión y mezcla de la gente, a las que atribuye la decadencia de los pueblos. En fin, todo parece estar permeado por las ideas del pecado, la culpa y el mal. Según el reli- 
gioso, en Guatemala la influencia del demonio era tal, que se habfa posesionado incluso de muchos espanfoles, que ya no se espantaban de las "abominaciones". De alli que se oponga a una máxima espafiola que él escucho durante su visita, según la cual "las cosas de la América han de permanecer y dejarse en el estado en que se hallan" (I,203). Para él, la misión principal, e incluso la única, era procurar la felicidad de los indios mediante una verdadera cristianizacion, es decir, erradicando su antigua religion. ${ }^{13}$

Una y otra vez, el parámetro de la religión católica choca y contrasta con sus propias experiencias en el campo, cual si fuera un antropologo no percatado de la carga de su propia cultura; como es obvio suponer, a lo largo de su visita, encuentra sacerdotes con quienes comparte su mismo modo de pensar. Por ejemplo, el cura de San Andrés Itzapa, a quien Cortés considera un anciano virtuoso, juicioso y un buen administrador, responde a sus preguntas diciendo que a pesar de su gran empeño por evangelizar a los indios, estos "nada espiritual creen, ni Dios, ni Trinidad, ni alma". Según $\mathrm{el}$, los indios son miserables porque carecen de la religion, porque viven sin su beneficio, dado que "la religion cristiana se establecio sin arreglo a las leyes del evangelio, precedió el bautismo a la enseñanza, debiendo ser al trocado..." (II,185).

La falta de religión es la causa de las deshonestidades y de los vicios, Objeto de constante critica es la desnudez en que vive la gente, como es el caso de los pueblos de El Salvador, donde "la gente anda tan vergonzosamente desnuda que apenas comencé a entrar en el pueblo, me espanté y me llené de confusión, hasta cerrar los ojos por no ver semejantes espectáculos... solamente llevan las mujeres un cotón ceñido a la cintura, que cubre hasta las rodillas; las muchachas y muchachos ya grandes nada y muchos hombres, un pedazo de trapo o pafiuelo nada más" (I,72).

No hay población, dice, que escape al vicio de la embriaguez, causada por la instalación de estancos y fábricas de aguardiente, donde los indios aprendieron a producirlo y consumirlo de la ma-

13 VEase al respecto sus reflexiones en Zacualpa y las recomendaciones al cura de Zumpango. 
nera en que se hace. Para él, es tan desenfrenado el vicio del aguardiente entre todos, indios, espafioles y ladinos, que considera imposible su remedio (II,195).

En general, la interpretación de Cortés sobre los rituales y las creencias religiosas se encuentra determinada por su idea de la magia, que abarca todas aquellas manifestaciones del demonio que existen porque no las ha exterminado el cristianismo. Ya desde el inicio de la obra se trasluce en el autor la idea de estar librando una batalla en contra de "los mágicos", con objeto de recuperar y salvar las almas de la gente. En la parroquia de Aguachapán, El Salvador, observa el prelado que ni siquiera los hacendados quieren asistir a misa ni a la doctrina cristiana y que lo mismo ocurre con cerca de la mitad de la gente de la diocesis. Para corregir tal situación, el prelado reconoce que no basta con órdenes ni censuras, ni con un mayor empefio y celo de los curas, que por lo visto no se preocupan de los vicios y excesos increfbles, "porque aunque no sean mágicos se han criado siempre entre ellos y asi no les causan espanto semejantes espectros" (I,67).

Evidencias de magia las encuentra en las conductas de su propia gente, con "mayor escándalo" en los religiosos, que han aprendido a convivir con toda suerte de monstruosidades, acostumbrados ya a las idolatrias y supersticiones de los indios. La fuerza de lo mágico es tal que gobiema absolutamente las vidas de la gente. Para ilustrarlo, compara las cosas que ve en estos pueblos, con una ciudad imaginaria habitada por muchos mágicos, quienes se entretienen "con los monstruos, con las fieras y con los difuntos, cuando los que jamás hubieran visto tales espectros la primera vez se morirfan de susto" (I,55). Un ejemplo de "los mágicos" se lo brinda un Oidor de la Audiencia, quien le relato el caso de un hombre agonizante a quien la gente rodeaba simplemente para verlo morir. El Oidor lo auxilio y logro salvarlo, ante la indiferencia de los otros: "todos se quedaron con mucha serenidad sin moverse a diligencia alguna" (Ibid.).

Otra crftica de Cortés es lo profano y dispensioso del culto religioso, que según dice, los mismos espaffoles han orientado más a 
la vanidad que a la devoción; él piensa que si los indios vieran en los españoles

menos codicia, menos deshonestidad, más modestia, más compasión, más caridad, puede ser que hubieran aprendido virtudes en vez de haber aprendido iniquidades; pero viendo que somos como ellos y peores, es de temer que se están en sus antiguas costumbres y que el culto que hacemos a los santos lo remedan ellos para hacerlo a sus ídolos, no perdonando todo género de gastos, porque es cosa espantosa lo que gastan en sus fiestas en candelas, plumas y aun embriagueces y deshonestidades (II,228).

Asf pues, para el arzobispo el problema más serio de la dícesis de Guatemala y posiblemente para el resto de América era el paganismo de los indios. Sus muestras de catolicismo las considera "exterioridades hipocritas", ya que en el fondo, "están estos miserables más inclinados a su gentilidad, que a la ley de Dios" (II,43). Tan grave e irresoluble encuentra esa situación, que piensa que la misma debe exponerse con toda claridad y fundamentos a la Iglesia, para que el Papa intervenga resueltamente en favor de una verdadera cristianización (II,44).

Ya hacia el final del informe, en sus reflexiones sobre la parroquia de Chiquimulilla, el prelado resume muchas de sus opiniones generales sobre toda la diocesis. Sus criticas principales son la mala administración de los curas y de sus coadjuntores, la crueldad y la explotación de las autoridades civiles contra los indios, el libertinaje en que vive la gente rural, las inmoralidades producto del hacinamiento de las familias en los "estrechos jacales", la aversion de los indios a la religión, las idolatras que llenan sus vidas, pues "para todas sus cosas tienen su f́dolo", la ineficacia de las pocas escuelas, a las que considera inútiles y hasta perjudiciales, ya que en ellas lo que menos se hace es educar a los niffos. Al respecto presenta el caso de las salinas y las pesquerfas de la Costa Sur, donde señala que alli se esconden toda clase de maleantes y viciosos. Aconseja a la Corona que la solución a dichos problemas serfa invertir en ese negocio, abriendo fábricas de sal, fundando pueblos con los trabaja- 
dores y con los vagos y viciosos de las parroquias, poniéndolos a cultivar esas tierras que son muy fértiles y sacando grandes utilidades y beneficios de tal empresa (II,221-224).

Sus observaciones durante el recorrido por la diócesis lo llevan a identificar ciertas tendencias generales sobre el futuro de estos pueblos. En las parroquias de la Costa Sur sefiala la decadencia y el abandono de varios pueblos que anteriomente eran prosperos y que sin embargo han desaparecido; "se han arruinado las provincias más floridas, ya no digo de Goathemala, sino de todo el mundo... si se sacaran de éstas los forasteros, vagos, se quitaria más de la mitad de la gente que habita" (II,275). La explicación que da a este fenómeno es que los pueblos están siendo invadidos por "forasteros y vagos" que traen consigo la comupción y los vicios; más que una "decadencia a causa natural, fundándola en la feracidad del país y poca gente que hay para cultivarlo" él la achaca a la "feracidad de sus vicios". Es por eso que mucha gente huye al ver sus pueblos invadidos, dejando en ellos a los forasteros viciosos.

Los españoles. A primera vista, la Descripción no ofrece muchos datos sobre los espanoles, como ocurre con los otros grupos, en parte porque describirlos no era su objetivo y en parte porque son de hecho una minoría, aunque claro, se trata de la minoría dominante, cuyos miembros detentan el poder económico, polftico e ideologico; su presencia en el país es determinante y a pesar que el arzobispo no centró en ellos su atención, están siempre presentes, a menudo en el trasfondo, cuando se habla del otro, es decir, de los indios o de los ladinos. Español es el autor del texto y por lo tanto dicha categoría es parte intrínseca del discurso del mismo; españoles eran los funcionarios de gobiemo, como el capitán general y sus oficiales, los eclesiásticos de alto rango, los alcaldes mayores, los corregidores, etc. y criollos los curas y los coadjuntores de las parroquias, ${ }^{14}$ de quienes aparecen observaciones fre-

${ }^{14}$ La carrera eclesiástica resultaba atractiva para muchos criollos españoles y ladinos, de allí las referencias sobre curas graduados en la Universidad de 
cuentes. En fin, espaffoles son aquellos cuyos intereses, aspiraciones y conductas en Guatemala las resume aquel refrán citado por Cortés: "aquf el aragonés es andaluz, el castellano gallego y el Pedro Fernandes, don Miguel Antonio Salazar Guzmán de Córdoba..." (I,141). En el mismo sentido va otro breve comentario suyo donde afirma que en estas tierras, cualquiera que tenga hacienda o dinero "quiere ser tratado como príncipe" $(1,160)$.

\section{Alcaldes mayores y corregidores.}

Todos vienen de Espafia endeudados; luego se empefian acá más para hacer sus repartimientos; se mantienen con abundancia y ostentación; no deja de ser preciso el regalar, y en el corto tiempo de cinco affos quedan (los que quedan por aca) hombres muy ricos, y los que se vuelven a Espana es con mucho dinero; y con más tal vez del que ninguno se persuadiría y como todo sale de los pobres indios, es preciso que sean muy molestados; y tanto, que es de admirar como no abandonen todos los pueblos... $(I, 285)$

Es claro para Cortés que los indios abandonan sus pueblos para escapar de los abusos y explotación de las autoridades espanfolas, sobre todo de los alcaldes mayores y de los corregidores. El que vivan siempre atemorizados, recelosos, mintiendo y ocultando su deplorable situacion, en vez de denunciarla y exigir justicia se debe, según el mismo lo atestigua, a la opresión que sobre ellos ejercen las autoridades civiles, a las constantes amenazas, azotes y demás castigos. Asf́ denuncia la tiranfa del Alcalde Mayor de Nebaj, donde los indios "ven que han de quedar bajo el azote del Alcalde, y más, cuanto más se quejen". Es por eso que prefieren mentir y disimular, aquellos que se atreven a denunciar las vejaciones que sufren, luego "se desdicen de lo que han afirmado y con esto se quedan siempre indios y por consiguiente sujetos a

Goathemala (cf. II,60), García Añoveros (op. cit. p. 26) seffala que casi todo el clero parroquial era originario de la dícesis. 
todos, tiranizados y sin remedio"15 $(\mathrm{II}, 50)$. Otro caso similar es el de la parroquia de San Miguel Totonicapán, donde en la plaza del pueblo, en vez de tener una picota se tiene a "un negro que toma de las manos a los indios, cuando los azotan; cuya invención de poco ha por el Alcalde Mayor, fue para que los indios azotados sientan mayor abatimiento" (II,102). Para Cortés, con tales actos se incrementa el horror, tedio y aversión hacia los españoles.

La codicia de alcaldes mayores y corregidores es causa de graves males para la población indigena, "todo lo atropellan por aumentar sus caudales, de modo que abrumados de tales extorsiones, mueren muchos y otros abandonan sus pueblos y familias" $(I, 273)$. A eso debe agregarse la violencia ${ }^{16}$ de los repartimientos que solo favorece a los espanfoles, a costa de la economía y la vida misma de los indios (I,296-297). Violento considera el reparto de algodón que sufren las mujeres chorties de Jocotán, quienes deben trabajar todo el affo en beneficio del corregidor $(\mathbf{I}, 270)$.

Los curas. De estos se encuentra abundante informacion, pues además de sus respuestas al cuestionario, Cortés se refiere a ellos y a sus coadjuntores de cada parroquia; en ciertos lugares, también da su opinión sobre las ordenes. Es interesante su opinión sobre los dominicos, expresada en su visita a la Verapaz, donde dice haber predicho con acierto, que contrario a las demás parroquias, en éstas no recibirfa ningún memorial en contra de los curas, sugiriendo que los dominicos mantenían un control férreo sobre los feligreses. Afima que sus informes son falsos, luego de contrastarlos con sus propias observaciones.

Advierte que los religiosos han puesto tan poco cuidado en instruir a los indios en el catolicismo y en la vida moral, que estos no perciben sus propias costumbres como incorrectas o malas. De alll que un indio xinca de Guazacapán, al ser reprendido por rendir

${ }^{15}$ Aquí el significado de indio marca la condición social de opresión y explotación del indígena.

${ }^{16}$ Con esto alude Cortés al carácter de coacción e imposición por la fuerza de este tipo de trabajo. 
culto a un fdolo en su cacahuatal, respondió al cura: "los espafioles también hacéis lo mismo y teneis las figuras que os han dejado vuestros padres..." (II,227).

Para el prelado, la única manera de establecer el cristianismo es trayendo curas de España, "que no estén criados entre tantas abominaciones de la América" y atando a los indios a los pueblos, aunque lo mismo aplica para espafoles, ladinos y a todos los habitantes, pues "donde menos gente hay es en los pueblos". Al respecto, recuerda que el cura de Huehuetenango "harfa empefio en ensefiar a decir la doctrina a los papagayos, pero no a los indios, porque los papagayos los tenfa atados y los indios estaban libres, fuera de los pueblos y a monte" (II,238).

A muchos curas los considera comerciantes, "mercenarios", "traficantes del ministerio" (I,99), que viven descansados, gozando de los beneficios y las rentas del curato, sin preocuparse del estado moral y religioso de sus parroquianos. Con tales curas, dice, no se puede esperar remedio a los vicios y desórdenes de la diócesis. Ese es el caso del cura de Zumpango, quien vive en ese pueblo para enriquecerse a costa de los indios, no para favorecerlos:

¿Quién con 2,000 pesos de renta, dice que no tiene para mantener un ministro, que considera (y es) necesario en una feligresía tan dilatada, sino semejantes curas, que en esto mismo ofrecen inevitable documento de la indiferencia con que miran la instrucción y salvación de sus parroquianos? ¿Sobra para construir un palacio bien superfluo y falta para tener un ministro necesario? (II, 81)

Otra razón importante que señala el arzobispo por la cual no se cumplen los preceptos de la iglesia es que en los pueblos no se encuentran los artículos indispensables para la vivienda de los curas; esa dificultad, dice, solo se comprende viendo esas restricciones, viviéndolas en el campo. Asf comenta que cuando un cura sale a visitar el interior de su parroquia, debe ir con indios y caballos para "llevar consigo la cama, la comida, la bebida, la silla, la mesa..." (I,98). 
Los curas manejan varios estereotipos, prejuicios y temores acerca de sus feligreses. Respecto a los indios de Comalapa el párroco del lugar piensa que "quien ve a un indio los ve a todos, por ser de un mismo modo". Según Cortés, todos los curas piensan que los indios cada vez son "más atrevidos", que "con el tiempo se van insolentando" $(I, 139,142)$. Con semejantes opiniones, no es de extrafiar que los curas y sus coadjuntores fueran tan crueles con los indios, como se deja ver en muchas de las quejas presentadas en las audiencias que el arzobispo sostuvo con estos últimos. Al igual que en otros pueblos, en Nebaj el cura podía ordenar al fiscal que castigara con 8 o 10 azotes a todo aquel que faltara a misa. Las confesiones se realizaban masivamente y a la fuerza: en las misas, "a pura violencia los meten dentro de la iglesia" (II,80); se dice que además, se cerraba la puerta de la iglesia para impedir que se salieran. En Matzahuat los indios se quejaron ante el prelado de estar siendo muy maltratados; en un caso reciente a uno de ellos lo habfan castigado con cien azotes. La respuesta del cura ante esa acusación fue simplemente que "habla sido un arrebato" (I,132).

Cortés expresa su indignación frente a las terribles condiciones de vida que sufren los indios, afirmando que no sería una exageración decir que a ellos "todos pueden castigarlos". En cambio, observa que los curas suelen ser "aficionados" a los ladinos, los privilegian y simpatizan con ellos, a pesar que según su opinión, los indios deberian ser "el principal objeto de su atención" (I,148).

\section{Guatemala india}

La cultura indigena fue uno de los grandes intereses del ilustre prelado. Quiso describir cómo eran realmente los indios, cuál era su carácter y en qué eran esencialmente distintos de los europeos, y conocer todo eso a través de sus propias experiencias, no de ofdas ni de informes de terceros.

En ocasiones, Cortés concuerda con opiniones generalizadas entre los espaffoles de la diocesis, como aquella de que los indios 
son incomprensibles, sin embargo, aclara que no comparte la idea de que éstos no sean advertidos, es decir que para él los indios sf eran inteligentes, racionales, conscientes. Su "idiotismo y estolidez" son para él defectos causados por la forma de vida, por crearse "desnudos al sol, al viento y a todo contratiempo, con lo que no pueden dejar de padecer mucha lesión en el cerebro" (I,172). Asf también reconoce que los indios tienen un método de registrar la historia y de administrarse, aunque el mismo le parece incomprensible, porque "su politica... es puramente maliciosa y tan contraria a las máximas cristianas" (I,173).

Le interesa definir lo que es "connatural" a los indios y lo esencial de su carácter. En un lugar dice que el genio de éstos se reduce al dispendio ostensivo de bienes y riquezas, pues a pesar de su pobreza, "gastan muchos reales en sus fiestas" (II,16). Sin embargo, por otro lado, piensa que los indios no son "afectivos". En sus reflexiones al informe del cura de Jocopilas afirma que "tienen los indios la parte afectiva tan sin movimiento, como si carecieran totalmente de ella, que mueren aún con menos indicios de sensibilidad que los animales, que carecen de razon... Lo que reciben es el Santo Oleo y esto, porque algunos se persuaden que es una pura medicina corporal... ¡Pero afectos en los indios!" (II,54).

En sus consideraciones sobre demograffa de Cubulco, Cortés identifica un rasgo distintivo de las familias indias, que contrasta con las españolas y ladinas. Para las primeras "su riqueza y abundancia consiste en tener muchos hijos" para tenerlos como esclavos y bestias de trabajo. Por eso, aunque se casen, los hijos viven con los padres y se consideran una misma familia. Esa es la causa de "infinitos divorcios... porque cada uno de los suegros quiere hacerse duefio de los casados y tenerlos en su jacal y sitio". Por el contrario, los espafíoles, "y aun ladinos" de la ciudad capital hacen lo opuesto, pues todo lo dan a los hijos. Una hija puede ir vestida como princesa, mientras que sus padres visten "hechos un andrajo". Según él, esa es la razón por la que tales nifios se vuelven "viciosos y vanos" (II,31). 
Por otro lado, las anécdotas y casos que relata el arzobispo a veces dan pistas sobre la concepción que los indios tienen de sf mismos. Una tarde, mientras visitaba el pueblo quiché de Zamayac, Quetzaltenango, salio a caminar y se encontro con un anciano hablante del castellano, quien iba acompanado de sus nietos. Luego de conversar con él un rato se atrevió a pedirle a uno de los nif́os para criarlo y educarlo, ofreciéndole acomodarlo y velar por su bienestar, a lo cual el anciano se nego rotundamente. Tratando de cambiar la conversación, el prelado le preguntó que por qué andaba descalzo, y el otro respondió que porque era indio. "Dfjele que los indios eran espanoles como nosotros; él replico que no era espaffol, sino indio. Repúsele ¿que si querfa ser espanfol?, respondió que no y habiéndole instado una y otra vez, insistió en decir abiertamente que no" (II,267).

Para Cortés, lo anterior es una muestra de "las ideas que de los espafioles tienen estos miserables". Y de hecho, la altiva respuesta del anciano expresa el reconocimiento de la diferencia y la defensa de su identidad indigena frente a la máxima autoridad eclesiástica, es decir, que alli se evidencia una posición india frente a la alteridad. Pero al mismo tiempo, la conducta y la intención de Cortés en este caso revela su posición de fondo con respecto a los indios: desea que dejen de ser lo que son, que se vuelvan cristianos, "espaffoles". Según él, los indios son inferiores por carecer de la religión cristiana, por ser ignorantes, sin educación, por ser naturales en vez de civilizados y por eso mismo es que son explotados y tratados como animales. Por eso es que deben dejar de ser lo que son, para adquirir la misma calidad humana de los españoles.

Las lenguas. Uno de los méritos del autor de la Descripción es el empefio por registrar las lenguas indigenas habladas en la diocesis; en eso consiste la segunda interrogante del cuestionario enviado a los curas párrocos antes de la visita. De alli que el texto ofrezca un detallado mapa lingüistico del territorio visitado. Por lo general, los idiomas mayores del Altiplano, como el quiché, cakchiquel, kekchi, pokomchi y el mam, se conservan en los mismos 
lugares descritos en el informe. En cambio, los idiomas del sur y oriente de Goathemala, con el tiempo han sufrido cambios radicales y en su mayoría han desaparecido. Tal es el caso del pipil o mexicano, ${ }^{17}$ que en aquella época se hablaba en lo que hoy es Escuintla, Jutiapa y prácticamente en todo el territorio de El Salvador. Incluso en Salamá se dice que se habla un idioma mexicano "muy corrompido".

Se subraya como un hecho generalizado que el mexicano no sea necesario para la administracion: “.... advierto que en todas las parroquias en donde es matemo el mexicano, saben, y hablan todos el castellano, pero sin abandonar el materno" (II,241). En el pueblo de Almolonga, vecino a Goathemala, los indios hablan el mexicano, pero todos hablan el castellano tan bien como el materno. Se admira, sin embargo, que en los otros pueblos alrededor de esa ciudad, el cakchiquel sea indispensable para la administracion, pues estos "por lo común nada saben, ni entienden el castellano" $(I, 41)$. Este fenomeno lo explica argumentando que el mexicano debe ser un idioma menos bárbaro, cuestionando la opinión de algunos, de que los causantes hayan sido los párrocos regulares, que conservaron las lenguas por su propia conveniencia. El dato es interesante, porque revela cómo la aceptación o rechazo a lo espanol está en relación con la historia y la sociedad indígena de que se trate: mientras que los cakchiqueles eran antes de la llegada de los espaffoles una sociedad polfticamente constituida y de largo arraigo en la region, los mexicanos o pipiles eran relativamente recién llegados, fuera por migración o por conquista.

El idioma chorti, hablado en Santa Rosa, en los pueblos de Chiquimula, en pueblo de Ipala, e incluso en Texuthla (El Salvador), lo hacen aparecer como vecino circundante del pokomam, hablado en Guatemala, Jalapa y Santa Catarina Mita, en Jutiapa.

17 Debe señalarse que Cortés toma a los idiomas pipil y mexicano como sinónimos, pero aunque ambos tienen su origen en el nahuatl del centro de México, los mismos son cronológicamente diferenciables, pues el pipil corresponde a una migración temprana del nahuatl a la costa del pacífico centroamericano, mientras que el otro era el hablado por los aliados mexicanos de los conquistadores. 
Hasta esa época, los chortíes parecen rodear a los pokomames del altiplano central. Para la historia de esta lengua cholana es interesante que se hable también entre los departamentos de Jalapa y Santa Rosa en la parroquia de Los Esclavos y en Acasaguastlán, El Progreso, donde "Los idiomas que se hablan son en la cabecera el chort y en los anexos el alaguilac" (II,283). ${ }^{18}$

El xinca, un idioma casi extinto en la actualidad, se reporta en los pueblos de Guanagazapa, Escuintla; en Chiquimulilla, Xinacantán, Taxisco, Tlacuilula y Guazacapán, del departamento de Santa Rosa, y en Jutiapa. En estos últimos, se menciona además al xinca-populuca, o sólo al popoluca (Moyuta y Jalpatagua) y puede indicar la presencia de los dos idiomas, o del zoque-popoluca, que también se hablaba en Jalpatagua, Conguaco y en Moyuta, Jutiapa. En todo caso, el xinca y el popoluca se hablaban en un territorio delimitado por el pipil al oriente y al occidente. El prelado dice que en Cuilco, Huchuetenango, se habla un idioma que all se le llama popoluca, pero que es una mezcla del mam y el chapaneco y agrega que los habitantes del vecino pueblo de Motozintla "lo hablan diferente que los otros, de modo que no entienden, ni son entendidos de los otros pueblos". 19

Cuilco es un caso interesante por mostrar lo complejo de las diferencias dialectales. Según Cortés, alli la mezcla de dos lenguas distintas da por resultado una tercera y piensa que ese contacto de lenguas indigenas ocurre en un pueblo cerrado, que tiene relaciones comerciales con un pueblo cercano de lengua distinta. También en Huehuetenango, el idioma hablado en la parroquia de Jacaltenango, llamado popoti, es muestra de la complejidad lingüistica regional, pues "aunque se reputa por mam, como también el zulumef̃o [de San Pedro Soloma], son bastante distintos".

18 Una fuente colonial más temprana también incluye a "los curatos de Chiquimula, Esquipulas y Casaguastlán" en el territorio de la "nación Chol [chorti] en tiempo de su gentilidad". Francisco Ximénez, Historia de la Provincia de San Vicente de Chiapa y de Guatemala, Guatemala, Sociedad de Geografia e Historia, 1930, tomo II, p. 10.

19 Se refiere al idioma moch 6 de la familia maya. 
Para Cortés, el que en Uspantán, además del quiché exista otro "que se dice musré... los cuales aunque tienen semejanza, pero también bastante diferencia" y que esto suceda en "todos los idiomas de los indios", es una evidencia clara del serio problema que esa gran diversidad de lenguas representa para la administración colonial. Considera que la mejor manera de administrar estas pamoquias es que los curas conozcan el idioma de su jurisdiccion, aunque como en los casos anteriores, el asunto es mucho más complicado, pues el multilingüismo se da incluso a nivel local. En la parroquia de Cuyotenango, en Retalhuleu, "se hablan tres idiomas: kiché, kacchiquel y sotogil y muchos entienden y hablan el castellano". Esta situación la explica diciendo que hay trabajadores del altiplano que migran hacia la costa y conservan su propio idioma. Lo mismo ocurre en San Antonio Suchitepéquez.

A lo largo de su visita, el prelado se enfrentó a una enorme barrera lingüistica y cultural que lo impactó profundamente, dejando escritas muchas de esas experiencias. En ocasiones, la imposibilidad de comunicación era tal, que lo llevaron a relatar anécdotas que ilustran la gravedad de la situación. En San Andrés Sajcabajá le sucedió que ni él ni el cura, hablante del quiché, pudieron hacer entender a los indios que iban a ser confirmados a que se lavaran la frente. ${ }^{20}$ Le pareció increible que no le entendieran algo tan simple, a pesar de habérselos indicado el cura en su propia lengua, que trat 6 de dar varias explicaciones al hecho, las cuales pueden resumirse en 1) la diversidad dialectal, 2) la "corrupción" y constante cambio de estas lenguas, y 3) la inferioridad de las mismas. Más adelante comenta que varios obispos han propuesto como remedio a este problema la enseñanza del castellano, pero él no cree que esa sea la solución, pues en esos idiomas no hay palabras para explicar los misterios del cristianismo, ni tampoco el castellano por sf mismo "puede suplir en los indios la pia afección que les falta... [ya que] en las provincia que solamente se habla el caste-

${ }^{20} \mathrm{El}$ sacramento de la confirmación era realizado exclusivamente por un obispo, que inclufa el poner el Santo Olco en la frente del confirmante, razón por la cual, el prelado pedía que antes de hacerlo se lavaran la frente. 
llano (y son muchas), son los indios tan ignorantes e idiotas, como en las que se hablan sus idiomas matemos" (II,39). Otros de sus argumentos sobre la inferioridad de las lenguas indigenas se encuentran en sus reflexiones sobre la parroquia de Comalapa, donde el idioma hablado "es el kacchiquel cerrado y no se entiende ni se habla otro". A pesar de sus opiniones positivas sobre este pueblo y sus habitantes, sefiala que

Con todo mientras los idiomas maternos dominen, no hay que esperarse mucho adelantamiento, porque son muy cortos y nada puede explicarse bien en ellos... Tengo por cierto que dichos idiomas son términos disparados, sin inflexiones, sin tiempos y que con cada término se significan varias cosas, de manera que ni los indios entre sf se pueden explicar, si no es con rodeos y ayudándose de las acciones... por consiguiente no pueden los indios ser instruidos en ellos (II,90).

Sin embargo, en seguida reconoce que hay quienes opinan lo contrario y por ello no considera que su juicio sea decisivo, sino más bien, una conjetura fundamentada.

Vivienda. Ya hacia el final del informe, al hablar sobre los xincas de Taxisco, el prelado dice que los indios son todos del mismo modo, todos andan desnudos, sin ningún pudor y aun a los dieciocho affos no llevan ni un hilacho en el cuerpo, con excepción de algunos que viven en las tierras frias. Viven en jacales en el bosque, como conejos; "en todos [los pueblos] comen de la misma manera, en todos duermen en tierra, en ninguno tienen un real; si cogen poco gastan poco, si mucho lo consumen en excesos, si les sobra, o se los hurtan, o lo entierran" (II,230). En tierra caliente y húmeda los indios viven en el bosque, sin formar un pueblo bien dispuesto, porque son desidiosos o por convenir a sus "ideas y caprichos". Piensa que vivęn asf para protegerse del cristianismo, para continuar sus vicios y vivir alejados de espafioles y ladinos, a quienes aborrecen, pero también para vivir separados de ellos mis$\operatorname{mos}$ (II,299). 
Al tomar a Escuintla para tipificar a los pueblos de la dícesis, luego de describir la plaza central, dice que el resto del pueblo no presenta ningún orden, no hay calles, todo es un derramamiento de jacales cubiertos de paja y metidos entre los árboles. Define al jacal como una "choza angosta de cuatro palos cubiertos de paja; en ella comen, viven, duermen y habitan promiscuamente los perros, las gallinas, los guajolotes, los cerdos y los indios; sin mesa, silla ni cama, y asi todos duermen en tierra... todos desnudos..." (II,299).

Gobierno indio. El texto es rico en datos sobre la vigencia de algunas instituciones de gobiemo indigena y de conductas asociadas con estas, aunque como ocurre en otros asuntos, la información está plagada de prejuicios, como el carácter degradado de los indios y su inferioridad, donde se refleja una concepción ideologica hispana opuesta a la existencia de formas autónomas de poder.

Tanto en este apartado como en el de creencias, aparecen elementos que indican la existencia de nacionalidades entre ciertos grupos indígenas, tal el caso de los quichés, que continúan con sus instituciones administrativas, con una organización social propia y autónoma y manifiestan una fuerte conciencia de identidad.

A veces, la oposición al gobiemo espafiol se manifiesta en los conflictos cotidianos con las autoridades eclesiásticas. Asf, en las reflexiones sobre Jocopilas, para mostrar "la tenacidad e incorregibilidad de los indios" el arzobispo relata cómo éstos le exigieron destituir al cura, por oponerse a que la gente del lugar saliera a pedir limosna cargando una cuna en tiempo de Pascua para hacer la fiesta. Además, amenazaron con quemar todos los jacales e irse al monte si no se cumplía con su exigencia. Con pesimismo, concluye el prelado diciendo que "La embriaguez y zarabandas y el poco remedio que tienen los vicios de los indios por su tenacidad, idiotismo, falta de crianza y de religión, no se pueden explicar". De igual manera, opina que los justicias, o autoridades locales de los pipiles de la parroquia de Atheos, en El Salvador, a pesar de que entienden y hablan el castellano, "son tan repugnantes a oir 
misa y la doctrina cristiana, como los demás del pueblo y en suma son $\tan$ indios e idiotas como los otros..." (I,97).

Los indios responden a la opresión de las autoridades de muchas maneras, desde las sutiles formas de resistencia hasta la franca oposicion, a veces ejerciendo su poder económico para hacer valer su voluntad y sus intereses. De alli que Cortés hable de una "Iglesia Americana" porque según él, a fin de cuentas "los legisladores son los indios", pues se hace lo que ellos disponen, ya que "la renta de los curatos consiste principalmente en lo que dan ellos" (II,102). En varias ocasiones le toc 6 vivir situaciones en las que sus disposiciones chocaron con la de los indios y como respuesta, éstos lo abandonaban repentinamente, dejándolo desamparado, con lo que se muestra que aquellos no estaban absolutamente impotentes ante el sistema de opresion, pues manipulaban a su interior sus propios recursos de poder. Esto lo resume el prelado más adelante, en sus reflexiones de San Cristobal Totonicapán:

Los indios son poco corregibles, porque su última razón para no admitir gobierno es que se huirán a los montes, que quemarán los jacales y que se perderán los tributos. Ellos no tienen más correctivo que el látigo a todas horas... son hombres que si algo hacen es por puro miedo y con éste hacen, dicen y contestan con verdad o mentira lo que quieren lo que tienen el látigo en la mano (II,106).

Para Cortés, existe una clara oposición indrgena hacia los espafnoles y ladinos, a quienes consideran "forasteros y usurpadores de estos dominios" (I,141). Observa que los indios de Patzún, reputados de "belicosos y de mala calidad", no hablan el castellano aunque lo entiendan porque "tienen aversión y odio positivo a todo lo que sea españolismo, lo que es general en toda la América" (II,93). Esto lo atribuye a que en realidad el gobiemo de los pueblos indios se encuentra en manos de tres o cuatro "oráculos", que imponen las mismas ideas a todos, como aquellas de que "los espanfoles los engañan, ... que la religion de sus padres es la verdadera..." $(I, 173)$. 
El calpul. Una muestra de la vigencia de instituciones de organización social indigena es el calpul, contra el cual Cortés lanza fuertes criticas. Con dicho término él se refiere más bien al jefe del calpul y no tanto a la institución en sf. Observa que en ciertos lugares "los calpules" reciben otros nombres, pero que en el fondo se trata de lo mismo. Asf, afirma que los calpules son "los que mandan y disponen todo, sin que haya otra voz que la de ellos en los pueblos" (II,91). Para él, son ellos la causa del casamiento prematuro entre los jovenes, práctica común en los pueblos, ya que con cada matrimonio los calpules se benefician al recibir ingresos: "casan a quienes se les antoja y perciben sus derechos". Por eso considera que los calpules, junto con los principales, son una peste porque esclavizan a sus compafieros indios y manejan todo a su voluntad, impidiendo la administración espanfola. Como remedio a lo anterior, propone la instrucción de indios jovenes para despojar del poder a los calpules, de manera que "todo el gobiemo corra por sus ayuntamientos" (II,139).

Un ejemplo del poder de estas autoridades indigenas se dio en Chichicastenango, donde la intervención del arzobispo para separar temporalmente a los conyuges de un matrimonio precoz, provoco la deserción de sus ayudantes, de los principales y el "alborotamiento" de la gente.

En el caso de Matzahuat, el cura atribuye la falta de justicia al hecho de que todos los casos pasan por el dictamen de los indios viejos, que suelen ser "parciales a los delincuentes", aparte de la "natural desidia" de las autoridades.

Pero por otro lado, Cortés también manifiesta su admiración por el trabajo de los principales, como los de Santa Cruz del Quiché, que llevan registros escritos pormenorizados de los acontecimientos importantes, la contabilidad de su administración civil, con independencia de los registros oficiales del Ayuntamiento y la Iglesia. ${ }^{21}$ De este mismo pueblo, el prelado recoge otros datos im-

${ }^{21}$ En San Sebastián Retalhuleu los principales del pueblo le pidieron "con mucha instancia y sumisión" un escrito donde constara lo ejecutado en ese pueblo para guardarlo en sus memorias. De alli que opine que el "idiotismo" no 
portantes de su historia antigua, indicando que en la llanura donde está situado existen muchos vestigios de edificios y que como alli la tierra es estéril, las sementeras se hacen en los pequeños valles formados por los cerros. Sobre el espíritu de nacionalidad quiché, seffala que ha recogido varios calendarios en uso y que entre los papeles deben encontrarse "raras historias del rey de Kiché; porque estos indios tienen (a mi parecer) muy vivas esperanzas de volver a tenerlo... hablan de esto con mucha individualidad y afición" (II,58). Y en efecto, casi medio siglo más tarde, los quichés de Totonicapán se levantaron en armas en contra del gobiemo, en protesta al cobro ilegal de tributos, para proclamar su 'independencia' y nombrar sus propios gobernantes, Atanasio Tzul y Lucas Aguilar. ${ }^{22}$

Así como existen instituciones de gobiemo indigenas, también siguen vigentes otras formas de orden social. Por ejemplo, en el pueblo de Quezaltenango, que reporta una considerable población de ladinos y espańoles, ambos clasificados juntos en la lista de poblacion, ${ }^{23}$ se dice que entre los "desordenes" de los indios están el no creer en el alma ni en la etemidad, quemar copal a sus deidades en las montañas, la existencia de "agoreros, curanderos y maleficios" y el poseer un calendario "para su gobierno":

... éste es el almanák de que se usa en todas las parroquias de kacchiquel y kiché, y en el mam, es el mismo, pero escrito en el propio idioma... se reduce a dirigir las acciones de los indios en cada uno de los dias del año... siembras y viajes, embriagueces, idolatrías y deshonestidades, según las atribuciones de cada día que hacen a los animales y aun al demonio, que es a quien suelen dar el mayor culto (II,156-157).

sea un vicio de la nación india, sino un producto "de sus caprichos y de carecer de los verdaderos medios para ser instruidos" (II,58).

22 Cr. Daniel Contreras, Una rebelión indigena en el Partido de Totonicapán, Guatemala, Universidad de San Carlos, 1968. Victoria Bricker, The Indian Christ, the Indian King, Austin University Press, 1981.

${ }^{23}$ Este procedimiento es poco usual en las listas de población dadas por el arzobispo, pero es muy significativo. Quizá se deba a que como ell mismo indica, "es pueblo crecido, abundante, con españoles, indios, ladinos y varias generaciones de éstos..." (II,157) [el subrayado es mío]. 
El prelado descubre que incluso las ofrendas, las limosnas y las misas en la iglesia están relacionadas con el pronóstico y con el día del calendario. En Mazatenango, el calendario es dominio de especialistas, "quienes tienen inteligencia de esta numeración" y el mismo rige el ciclo de fiestas, en las que se disparan muchos cohetes y luces. All también describe un tipo de fiestas llamadas zarabandas, que son comunes en toda la diocesis:

consisten en que desde el principio de la noche se junta en una casa o jacal todo género de gentes, hombres, mujeres, casados y libres; tienen su música y bailes toda la noche hasta amanecer el día siguiente; hay comidas, bebidas y embriagueces, como también toda especie de deshonestidades sin el menor rubor ni reparo... (II, 251).

Su curiosidad por las rafces de determinados vocablos y la definición de ciertos términos lo lleva a recopilar datos interesantes. Por ejemplo, reporta que la parroquia de Matzahuat tiene caminos pésimos porque su geograffa es un "laberinto de cerros y barrancos muy elevados y profundos" y que por eso mismo se llama Tepezontes a los pueblos de San Juan y San Miguel, "que en su idioma quiere decir veinte veintes de cerros". ${ }^{24}$ Su explicación del vocablo se reduce a que "los indios siempre cuentan por veintes", aludiendo al sistema numérico vigesimal. Sin embargo, en seguida agrega que según él entiende, de estas "etimologfas y derivaciones (muy frecuentes en la América) no debe hacerse mérito alguno" $(I, 130)$, reservándose las razones de tal opinión para otro caso más oportuno, sugiriendo con ello que existen muchos casos que prueban ese argumento en contra de los sistemas de conocimiento indigenas.

Las creencias. A lo largo de su viaje, Cortés encuentra variadas manifestaciones de lo que él llama idolatrías y magias, que su misma profesion religiosa lo lleva a interesarse en ellas. Hubo

${ }^{24}$ Del nahuatl tepe 'cerro', zontle 'cuatrocientos' (unidad de medida). 
hechos que lo sorprendieron enormemente respecto a las creencias, cultos y prácticas mftico-religiosas de los indios. Por ejemplo, ya desde el inicio de la visita le acontecio que en el pueblo de Caluco, cercano a Sonsonate, los indios decfan estar muriendo a causa de habérseles cortado la ceiba del pueblo y por eso mismo han enfermado y abandonado sus cacahuatales.

Llama la atención del religioso el culto que los indios dan a los animales del bosque, en particular el culto al venado, que él registra entre los mames de Malacatán, los quichés de Sacapulas y los cakchiqueles de Sumpango. En sus reflexiones sobre la parroquia de Huehuetenango, nos habla del Xaqut Coxol, nombre propio del Señor de los animales, a quien se rinde un culto especial relacionado con la caza. Refiere que el párroco le contó que para cazar un venado, primero se hace un ritual para pedir permiso a su duef́o, luego van a colocar las trampas y cuando cae alguno, hacen varias ceremonias para matarlo. Si es hembra le ponen un paffuelo en la testa y si es macho le adoman las astas, haciéndolo saber a la comunidad con un silbato para que los salgan a recibir con inciensos;

siendo macho sale a recibirlo el hombre más condecorado de la casa y si es hembra la mujer; en llegando al jacal lo ponen sobre un petate con una o dos candelas encendidas a cada lado; repiten sus oraciones y después de haberlo comido, guardan a buena custodia los huesos... (II,119-120).

En Panajachel, encontró creencias sobre un pajaro llamado pich y sobre el tecolote, con quienes los indios acostumbran hablar, otras creencias del lugar se relacionan con el ruido del fuego. Además, los indios sahuman a los santos y a la cruz, esta última es objeto de culto en los montes, llevándole flores y copales. Todo lo anterior lo lleva a afirmar que los indios no son cristianos, a pesar de su aparente devoción y culto, pues en el fondo siguen siendo politeístas, adorando a sus antiguos fdolos (II,169). Tan es asf, que también los cakchiqueles de Santiago Sacatepéquez y los de El Tejar rinden un culto a la muerte con mucha 
"publicidad", arguyendo que ésta es más poderosa que Jesucristo, pues logro quitarle la vida. “... se remedió la publicidad, quemando y destruyendo las estatuas de la muerte; si también ha cesado el culto lo sabrán los indios" (II,181). Por supuesto, el llamado culto a la muerte continúa en la actualidad, también con mucha "publicidad"; en lugares como Santiago Sacatepéquez se ha convertido en un atractivo turístico, pues el difa de los difuntos se acostumbra volar barriletes [cometas] gigantes en el cementerio local. Al igual que en otros casos ya mencionados, en vez de erradicar las creencias, los ataques a éstas podfan producir efectos contrarios.

Otra de sus observaciones sobre idolatrías se encuentra en la parroquia quiché de Zamayac, al describir las prácticas de los curanderos llamados ahcunes:

cuando eran llamados para curar a los enfermos, los conducían al monte y ante una ceiba encendian candelas, quemaban incienso $\mathrm{e}$ invocaban al dios del monte llamado en su idioma RahaualHuyub y antes de ir al monte hacian que los enfermos se confesaran ante una candela (II,268).

Con respecto a los nombres propios de personas, dice el obispo que por lo general en los libros de administración los indios no presentan sobrenombres [apellidos] y aunque las autoridades han intentado dárselos, ellos se oponen, pues el no tenerlo les sirve para ocultar su identidad. En todo caso, los sobrenombres son irregulares, “... no tiene un hermano el mismo que tiene el otro, pero ni el hijo tiene el de su padre... son los nombres de varios animales... los llaman sus nahuales y quiere decir sus protectores, a quienes se encomiendan, e invocan en sus necesidades... tienen grandísima aficion y aun veneracion a los animales brutos, de manera que desean en las iglesias estatuas de santos que los tengan..." $(\mathrm{I}, 103)$. En el mismo lugar, recuerda que a su paso por Tequtxistlán, del obispado de Oaxaca, preguntando por las "cosas de los indios" a un cura, éste le conto con respecto al nahual que "luego que nacen los nifnos, rodean los jacales con 
ceniza y hasta que ven en éste vestigio de algún animal, no los llevan a ser bautizados; en viendo algún vestigio lo ofrecen al animal y los llaman de su nombre y dicho animal es después su nahual".

En la parroquia de Mexicanos, en El Salvador, también se registran costumbres y creencias de los pipiles, como lo son sus prácticas funerarias. Antes de sepultar a sus muertos, los vestian con prendas relacionadas a su vida:

a las hembras adultas [con] una servilleta amarrada en la barriga. como la usan para moler acá, para que aś muelan allá. $\mathrm{Y}$ el pafuelo en los varones, especialmente en los principales que han gobernado acá, para que galanos (en ellos es uno y el principal adorno) gobiernen allá, llevando la mejor ropa que tenfa debajo de la mortaja $(I, 120)$.

Otra práctica funeraria de los pipiles salvadorefios era el nahuite o 'última despedida', que consistra en que al cabo de 4 dfas del fallecimiento, los parientes del difunto se reunfan para despedirlo, "esperan que venga el difunto a despedirse, y en efecto viene el diablo y haciendo un gran ruido en el tapanco de la casa, se despiden diciendo: adios, adiós" (I,119). En esa ocasion se da al difundo un obsequio, "poniendo en la cama donde murí atoles, gallinas y otras viandas de su uso; persuadidos a que viene el difunto ese día a despedirse de su casa y parientes, cuya venida esperan cantando alabados y otras oraciones, con que parece lo llaman" $(I, 133)$. Es interesante que el prelado afirme de manera implícita su propia creencia en los hechos sobrenaturales descritos, como lo indica el decir que "en efecto viene el diablo".

\section{Economia}

... Los indios en todas partes ni son ricos ni pobres, porque si tienen poco, gastan poco, si mucho, mucho, y en suma lo malogran todo $(\mathrm{I}, 249)$. 
A pesar de las duras y constantes crfticas a la sociedad indigena, el prelado también reconoce que muchos de sus males no les son propios, sino que son impuestos desde fuera, en especial por las autoridades coloniales. Cierto que los pokomames de San Luis Jilotepeque son poco trabajadores, dados a la embriaguez y tienen la costumbre de cambiar mujeres, pero más graves daños les ocasiona el repartimiento, que los aniquila al emplearlos como cargadores de las mercancías y cargas de los barcos del Golfo de Honduras, y los males que por lo mismo ocasiona la ausencia de los hombres en el hogar y el abandono de sus sementeras. Otra fuente de males y sufrimientos para los indios son los llamados alcaldes mayores, que mantienen un sistema de explotación basado en el terror y la represión, como ya se vio con anterioridad.

En algunos lugares, Cortés subraya las virtudes de los indios relacionadas con su esplritu de empresa. Observa que los pokomchres de Taltic, Tamahú y Tucurub consechan abundante maíz y frijol y que desde fechas recientes también en este último se cosecha cacao y algodon, "con lo que siendo antes pueblo pobre, en el día ya los indios son ricos". Lo mismo ocurre con la parroquia de San Cristobal Verapaz, que como los demás indios de esa provincia, se dedican a comerciar con otros pueblos. Los kekchies de Cobán negocian el algodon que traen de Cahabon, "hay muchos talabarteros que trabajan y bordan sillas con perfeccion" y en general los de Verapaz son los mayores negociantes de todas las provincias. Agrega como un caso excepcional, que en San Pedro Carchá, el maestro era indio y además "muy castellano".

Los ya citados cakchiqueles de Patzín los reconoce como los más laboriosos, al obtener mucho dinero de la madera que venden a la capital. En pueblos como Ixtahuacán y Utatlán en Sololá y Sija en Totonicapán, Cortés observa la introducción de cultivos nuevos como la papa y el trigo, asf como "algunos ganados de lana", que junto al comercio con los pueblos de la costa los hace ser "indios muy ricos", aunque muy viciosos (II,158). La Costa Sur es la zona de mayor productividad agrícola, pues tiene tres cosechas de mafz al afio y según estimaciones de Cortés, "podrían 
ser más, pues se cogen a los dos meses de sembrados, cuando en tierras de buen temple tarda seis y ocho y en las que se dicen frias tarda cuasi un afo" (II,256). Los quichés de Mazatenango emplean en sus tierras a trabajadores migrantes al igual que en los demás pueblos de la costa, donde sigue siendo importante el cultivo del cacao; "se sirven de indios forasteros, que van a hacerles sus trabajos, como es costumbre y saben todos, porque los indios de la costa no trabajan" (II,252). Esto es importante, pues evidencia que la migración laboral a las tierras bajas es una práctica común, del conocimiento de todos, que se remonta por lo menos a aquellas Epocas y que involucra la explotación de unos indios por otros.

\section{Los ladinos}

Una categorfa social básica en la concepción de la sociedad guatemalteca de Cortés y Larraz es la de ladino. Sin embargo, en el texto, él la emplea sin definirla de manera explícita, quizá por parecerle obvia y evidente, como lo era la de indio. Asf las cosas, una tarea a realizar es la de esclarecer sus significados, a partir de los mismos datos que él nos brinda.

Un primer problema es que si bien Cortés maneja una concepción global sobre los ladinos, a lo largo de la obra éstos no aparecen como algo homogéneo, siendo los de una región muy distintos a los de otra. Los ladinos que habitan en la capital tienen poco en común con los del suroriente y éstos a su vez distan mucho de los ladinos del altiplano occidental. Consideremos las siguientes referencias.

El texto trata con atención la situación de los ladinos rurales que habitan en las haciendas, ${ }^{25}$ en los valles, en los trapiches y en las salinas, y también en los pajuides, donde se refugian gentes

25 Severo Martinez reconoce que la obra de Cortés permite adentrarse en el "mundo licencioso, miserable y violento de los ladinos rurales", gestados en la finca espaffola y producto del mestizaje. De allí que diga que los trabajadores de las haciendas "siempre son ladinos" (op. cit. 284). 
que nadie conoce, "matadores, ladrones, amancebados y vagos de todas partes" de quienes ni siquiera los curas se preocupan $(I, 55,78)$. Así también se refiere a los trabajadores temporales de las haciendas, o escoteros, quienes "hoy están en esta hacienda y manfana en otra" $(I, 78)$. Lo mismo ocurre con incontables personas que no pertenecen a parroquia alguna y que viven en las salinas a lo largo de las doscientas leguas de costa $(I, 54)$.

De las observaciones de Cortés se desprende que los ladinos de la diocesis no siempre eran mestizos producto de la mezcla biologica entre espanol e indigena. Asf, en la descripción de Acasaguastlán él marca la distinción entre unos y otros, al afirmar que en esa feligresfa, "la mayor parte de ella es de mestizos y ladinos, y aun dudo que la tercera parte sea de indios". En lugares como Chalatenango, los ladinos aparecen en las estadísticas clasificados junto a los españoles, o en parroquias como San Vicente, con los negros y mulatos; all el prelado comenta que ladinos, mulatos y negros compartian creencias comunes, pues desenterraban huesos de difuntos enterrados en la iglesia, usándolos como amuletos para evadir a la justicia. En el sureste de la diócesis, es común que se llame ladinos a aquellos españoles "venidos a menos", a esos que "se dicen españoles", pero que no lo son debido a su situación social. Tal sería el caso de los descendientes de los "eclesiásticos amancebados" de Zacapa.

Poblamiento. Las estadísticas de Cortés no registran a una considerable parte de la población, en especial a la gente del campo, como él mismo reconoce. Aun asf, las cifras demograficas que nos brinda son significativas. De los 421,147 habitantes para la diocesis, 68.221 son ladinos, distribuidos la mayoría en pueblos de indios, otros más en 11 villas y un reducído número en 4 ciudades con españoles. El sureste de la diocesis presenta la mayor concentración de población ladina. ${ }^{26}$

En la Despcripción la primer referencia a los ladinos son las

${ }^{26}$ García Añoveros, op. cit.. pp. 18-19; 193-203. 
377 familias del barrio de la parroquia de Nuestra Seffora de los Remedios, en la ciudad de Goathemala. El prelado los define, al igual que en las parroquias vecinas, como aquellos que hablan el espafiol y no asisten a la iglesia, en contraste con los indios, que hablan el cakchiquel y que son devotos. Muchos ladinos viven en Almolonga y en el Valle de las Calderas todas las familias son de ladinos. En el pueblo de Petapa convivfan "espanoles, indios y ladinos", hasta que una inundación del ró del mismo nombre lo destruyo, creándose Nueva Petapa de indios y la Villa de la Concepción de los ladinos (I,47).

Las citas a los ladinos son frecuentes en los poblados que circundan a la capital, en especial para sef̂alar lo perjudicial que son para los indios: en Sumpango los indios son alfareros y van a la ciudad a vender sus productos y cargas de leña, pero todo lo dejan en las "aguardienterias". El cura del lugar dice haber tomado medidas contra ese problema, entre ellas, ahuyentando a los ladinos, "que venfan de Goathemala a fomentar las bebidas y los juegos". Más adelante, en sus reflexiones sobre el pueblo de Jocotenango, contiguo a la ciudad, el prelado nota que los ladinos tienen sus ventas de aguardiente, a donde los indios pasan a beber en el camino de regreso a sus pueblos: "consumen cuanto tienen, hasta el vestido que llevan".

Muchos son los argumentos de Cortés acerca del carácter pemicioso de los ladinos; por ejemplo, el problema educativo en Alotenango consiste, según él, en que los maestros de los nifios indios son ladinos y mulatos y su conducta es perjudicial por sus "embriagueces y deshonestidades": la solución que plantea es la de destituir a estos de sus puestos y suplantarlos con eclesiásticos, por ser ese un trabajo muy delicado (II,189). Lo mismo se indica sobre los maestros de Chiquimulilla, que perjudican a los nifios con sus malas costumbres, pues viven "indios y ladinos mezclados", hacinados en los jacales unos con otros. En dicho pueblo, se dice que los ladinos suman unas 500 personas y que han introducido el abuso de "velar a las criaturas contra la piedad cristiana con músicas y zarabandas", aunque asisten a misa y a la explicación de la doctrina cristiana. 
En la Alcaldía Mayor de San Salvador, los ladinos suman ya una mayoria. En el pueblo de Opico, cercano a la ciudad, se dice que ladinos y espaffoles conviven en las haciendas y en los valles, en las tierras fértiles y de agua abundante, pero en medio del desorden y la ignorancia: "ni hay templo, ni escuela, ni sujeción ni gobiemo y cada cual vive a su antojo". Según el prelado en estos lugares también viven algunos indios, "para el servicio y ciertos trabajos que solamente hacen ellos" $(I, 289),{ }^{27}$ pero lo común es que vivan en pajuides, rancherfas, hatos o estanzuelas, o en los lugares agrestes donde puedan establecerse (I,215).

En el pueblo de San Miguel, Cortés sefiala otros rasgos negativos propios de los ladinos: "Este terreno se halla inundado de ladinos y facinerosos... Con el motivo de hallarse tan dominante el vicio de juego, para robar a los jugadores el dinero úsase una diablura que practicaron al principio los negros....".28 En Conchagua, cercano a San Miguel, el prelado habla de ladinos que viven en pajuides como "personas muy viciadas y que mudan facilmente de domicilio". El curato de Santa Ana "se compone lo más de ladinos", casi no hay indios ni gente desnuda, "cuasi todos serán algunos españoles y los restantes ladinos y asi lo manifestaba el traje de todos". Esto es importante, pues el vestir ropas se toma como una diferencia notable entre indios y no-indios: mientras los indios andan desnudos, españoles y ladinos cubren su desnudez.

En Chalchuapa se identifica una situacion interesante que muestra una tensa relación "interétnica", pues a pesar de que la mitad de sus habitantes son ladinos, los indios restringen su crecimiento al impedir que aquellos "levanten casas sin su licencia", lo cual el arzobispo elogia diçiendo que "yo deseaba inspirarles esta política a todos los indios de la América" (I,231). Esa misma opinión en contra de los ladinos la enuncia más adelante, al

${ }^{27}$ Lo mismo dice respecto a la hacienda Ravinala, en San Andrés Sajeabajá, donde "es regular [que el ladino] tenga algunos mozos para cuidar del ganado y hacer alguna siembra de maíz para su abasto" $(1,36)$.

28 Véase lo que se dice atrís sobre los ladinos de San Vicente. 
afirmar que para terminar con los vicios y el desorden de éstos habria que "quemar valles, rancherias y pajuides, reduciendolo todo a pueblos".

Pajuides ladinos. Argumento constante del prelado sobre el desorden y corrupción imperantes, es la existencia de pajuides. ${ }^{29}$ Según Cortés, los pajuides de ladinos son numerosos asentamientos no autorizados, dispersos por toda la provincia y habitados por "personas muy viciadas y que mudan fácilmente de domicilio" $(I, 166)$.

En San Juan Sacatepéquez se dice que los pajuides son abundantes, que en ellos "se vive con toda libertad y al capricho de cada uno sin sujeción ni ley, en un idiotismo deplorable... el objeto principal de sus habitadores es huir la sujeción al Rey y a la Iglesia"; vive all gente de diferentes parroquias, sin religion ni civilidad, "unos que se dicen españoles, otros indios y otros ladinos". A diferencia de las aldeas y pueblos indigenas, estos eran asentamientos irregulares donde se refugiaban y mezclaban individuos de todo tipo. Como prueba de lo anterior, el prelado asegura que en las partidas de difuntos de los libros eclesiales de la parroquia, se lee en cada página "no recibio los sacramentos, porque murio en el monte" (II,200).

Más adelante, al referirse a los pajuides, trapiches y labores de la parroquia de la Asunción, Cortés indica que "Todos son una mezcla y confusión de espaffoles, indios y ladinos, y aunque en los pueblos la mayor parte será de indios, pero fuera de ellos serán muchos de espafioles y ladinos" (II,207). De la misma parroquia, afirma que en tales poblados vive muchisima gente al margen de la ley y de la religion, "concurren los indios, como a refugio para no tener religion: los amancebados para reputarse como casados; los ladinos para ser ladrones y matadores, y los espanfoles para vivir con la libertad que ofrecen estos paises" (II,208). Sobre el número total de este tipo de poblados, se dice que tan solo en el pueblo de Coxu-

29 Tipo predominante de asentamientos aldeanos, propios de las comunidades indigenas. 
tepeque existen 500 trapiches, pero que en las salinas "ninguno sabe, ni se puede saber a qué número ascienden... Los pajuides ascenderían a muchos miles, si pudieran numerarse, porque los hay en muchísimos pueblos y en bastante número. Algunas haciendas pueden dejar de aparecer en el escrito y en el resumen por no haberse dado noticia de ellas..." (II,295).

Ladinos en pueblos de indios. Una gran preocupación del arzobispo fue la presencia y expansión de los ladinos en los pueblos indigenas. De all sus agudas observaciones sobre el impacto economico, psicologico y moral en estos últimos. Su descripción va acompafiada a menudo por fuertes criticas a la falta de moral y los malos hábitos de los ladinos, a quienes considera como una plebe degenerada. Esta opinión es en sí misma reveladora, pues sugiere cuál era la condición social de aquellos.

En ningún caso ve la convivencia de indios y ladinos como algo positivo o de algún beneficio. En sus reflexiones sobre la parroquia de Soloma y de sus pueblos anexos. Cortés elogia la sencillez, la docilidad y el candor de los indios de las montafias Cuchumatanes, atribuyéndolo a la ausencia de ladinos. Para $\mathrm{el}$, la solución al problema consiste en dividir a unos de otros y agrupar a los ladinos en pueblos separados y sujetos a la ley de Dios y del Rey. Así terminaría el estado de injusticia prevaleciente, donde todo se carga sobre los indios "y aun los mismos ladinos los miran como esclavos y se sirven de ellos para todo, sin que ellos quieran servir a ninguno". A continuación recuerda como "no puede haber ministro en pueblos de ladinos, como se ve en el de Quaxiniquilapa, porque en nada quieren darle asistencia, sino que han de venir de otros pueblos los indios a darla" (II,125).

En Jacaltenango, provincia del altiplano occidental con una población de 2711 personas, el prelado habla de un tipo de ladinoindio: "hay uno u otro ladino, que apenas llegaran a treinta y tan indios en su parte, como los indios, y sin más idioma que el de éstos". Con esto sugiere que algunos se nombran o se les reconoce como ladinos. pero que en importantes aspectos son indios. Tal es el 
caso de numerosos pueblos la misma region. No siempre se trata de una minoria, pues en Chiantla, por ejemplo, pueblo "en muy buena situación y muy alegre, la gente anda vestida", sus registros civiles indican que mientras 67 familias indias suman 179 personas, hay 66 familias ladinas con 259 personas. Además, el idioma de esa parroquia es el mam, y en la cabecera, por haber tantos ladinos, todos entienden y hablan el castellano (II,132).

Cortés realiza severas criticas de orden jurfdico, denunciando las graves injusticias y desigualdades sociales al interior de los pueblos. Las evidencias sobre muertes violentas en Alotenango y la impunidad de los criminales llevan al prelado a reconocer que los espafioles y ladinos de los pueblos indios no tienen a nadie que los juzgue ni les administre la ley:

no hay... otros jueces. ni justicia que los mismos indios, los que podran aprisionar y castigar a los mismos indios, pero de ninguna suerte a los que se dicen espafioles, ladinos, mulatos, etc., con que habiendo tantos de estas generaciones en los pueblos ¿quien castigará sus delitos?... ninguno... (II,190).

Ese énfasis puesto en "los que se dicen", sugiere la existencia de un mecanismo de adscripción a una u otra categorfa social, utilizado para evadir la justicia, es decir, que el ser reconocido como miembro de una de ellas podía librar a un criminal de ser juzgado por sus delitos. Los indios en cambio si son duramente castigados por curas y justicias, quienes según Cortés, se complacen en hacer azotar a los indios, muchas veces sin motivo justificado y por asuntos por los que "no se azotarfa si no fuera indio".

... con bastante frecuencia oigo sus clamores y llantos desde mi cuarto, o aposento y aun los latigazos de bastante lejos, $y$ no he sabido contener mi sentimiento, diciendo: estos miserables son unos necios en venir a Goathemala a traer con tanto afín los viveres que necesitan, sino dejarnos en cualquier necesidad y perecerfamos ciertamente si diariamente no nos trajeran lo necesario para vivir... Verdad es que beben aguardiente con demasía. Pero ¿por qué no se amarran a las picotas a los ladinos que se lo ven- 
den y lo trabajan y lo tienen en los caminos de manifiesto? (II,286).

El despojo de tierras por parte de los ladinos es otro aspecto documentado en la Descripción. En Santa Lucía Cotzumalhuapa, parroquia rica en producción de cacao, Cortés dice que los indios están siendo expropiados de sus tierras de cultivo por los ladinos, con la colaboración del Alcalde Mayor (II,289). A su paso por esas parroquias de la Costa Sur, observa un proceso de decadencia y abandono de varios pueblos que anteriormente eran prósperos y que en muchos casos han incluso desaparecido: "se han arruinado las provincias más floridas, ya no digo de Goathemala, sino de todo el mundo... si se sacaran de ésta los forasteros, vagos, se quitaría más de la mitad de la gente que la habita" (II,275).

La explicación a estos hechos es que los pueblos están siendo invadidos por "forasteros y vagos", léase por los ladinos, que traen consigo la comupción y el mal. Por ello, más que una decadencia natural, fundada en "la feracidad del pafs y poca gente que hay para cultivarlo... tal vez consiste más en la feracidad de sus vicios" (II,275). Ese abandono masivo de pueblos antes prosperos lo atribuye también a los abusos y explotación de las autoridades locales, en particular a los alcaldes mayores.

En fin, es interesante la manera como Cortés describe a los ladinos, como los concibe y los prejuicios con que los juzga. Ve en ellos una especie de plebe, de gente corrupta, sin arraigo, sin moral, que está produciendo graves daños a la población indígena. A veces da la impresión de hablar de ellos como tratando de no evidenciar ciertos hechos, como ocultando un 'pecado original': los ve como hijos del pecado, resultado de la unión ilegitima de los españoles con los demás; son como bastardos sin ley, educación ni moral cristiana, vagos que deambulan por el pars, viviendo en el monte como animales, invadiendo pueblos indios, llevando consigo el vicio, la deshonestidad, la comupción y la muerte. Son ellos, aunque no de manera exclusiva, los que pervierten, engañan, explotan y roban a los indios, quienes se apropian progresivamente 
de las tierras, de los pueblos, del pars. Son ellos una de las causas fundamentales del grave estado moral de la diocesis.

\section{La sociedad guatemalteca}

... porque en todas partes ensefia la experiencia, que en los pueblos que entran los ladinos, se consumen los indios (II,256)

Desde un inicio la Corona estableció fundamentos jurídicos que normaron a la sociedad colonial y fueron creando el sistema de estratificación social en Guatemala. En un régimen de privilegios que no reconoce a los miembros de la sociedad como iguales ante la ley, indios, españoles y ladinos ocupaban necesariamente estatus distintos. Las Leyes de Indias eran el instrumento jurídico para la administración de justicia a la República de Indios y a la República de Espafioles, cada una con su propio cuerpo legislativo. Los ladinos no existían jurídicamente, no existía una legislación particular para ellos, a pesar de constituir ya un porcentaje alto de la población y una masa social en ascenso.

Si bien dicho criterio jurídico sobredeterminó a las opiniones de Cortés y Larraz, su interpretación de la sociedad guatemalteca fue regida por su concepción cultural del mundo. Utiliza de manera critica las nociones sobre la sociedad y sus miembros, que ha heredado de su propia gente, es decir, empleando las categorfas sociales en uso, la nomenclatura hispana sobre los diferentes grupos. Estas categorias tenfan un significado histórico y a la vez cotidiano, se fundaban en criterios raciales y valorativos, distinguiendo a la gente según su raza, apariencia física, condición social, religión, cultura: indios, españoles, negros, mulatos, castas, mestizos, ladinos, etc. La sociedad estaba hecha del conjunto de relaciones entre estos grupos, sociales y culturales a la vez.

La relación entre indios y ladinos fue para Cortés el punto central de su discusión sobre los problemas sociales de la diócesis. Esto se ve desde el inicio de su viaje, al relatar que en el pueblo de Santa María de Jesús, cercano a la capital, los nifos llevan un 
gorro o paffo que les cubre hasta la nariz, "para que no les haga mal, porque si les ve algún ladino la cara se enferman" $(I, 36)$.

Demografia. Lo que hoy es El Salvador presenta una situacion particular, pues en ella los indios son en su mayorfa pipiles, hablantes del 'mexicano', muy influenciados por la presencia espanola y ladina ${ }^{30}$ En la ciudad de San Salvador se registran 901 familias de españoles y ladinos, sumando 7118 personas; la ciudad "se compone de toda especie de espafioles, ladinos, mulatos, entre los que hay muchos vagos y haraganes" con exclusión de la población indígena.

En dicha ciudad, "que se dice de españoles", no hay escuelas, ni tampoco en los pueblos, de manera que para el prelado no es de extrañar que también los indios tengan repugnancia a la educación (I,107-108). Cortés observó que en esa alcaldia eran muchos más los ladinos que los indios y que tendían a vivir separados, pues en su viaje a San Jacinto los jacales a la izquierda del camino eran de indios de esa parroquia, mientras que los de la derecha eran de ladinos de San Salvador. Senfala además que el pueblo estaba poblado por ambos grupos y describe al cura como un "hombre vacio y belicoso. engreido de ser descendiente de los conquistadores... muy amante de los ladinos y muy desafecto de los miserables indios" ${ }^{31}$ En el mismo pueblo, el obispo resolvi 6 una acusación de brujerfa, liberando a seis indios que el cura habfa mandado encarcelar, luego de probar su inocencia y la mala intención de aquel, que sólo quería demostrar su lucha en favor del cristianismo (I,111-114).

Como ya se hizo notar con anterioridad, en los pueblos de la provincia de El Salvador. Cortés tiende a identificar un tipo de

\footnotetext{
${ }^{30}$ Según sus estadísticas, casi la cuarta parte de la población de la dícesis se encuentra en la alcaldía mayor de San Salvador, y concentra la mitad de la población ladina.

${ }^{31}$ Esta afinidad entre curas (criollos en su mayoría) y ladinos, en contraste con el desprecio ejercido hacia los indios, refleja las alianzas y oposiciones intersocietales (cf. I.148).
} 
españoles con los ladinos, en oposíción a los indios. Asf, en Chalatenango, "las familias de indios de esta parroquia son 193, con 836 personas y las de ladinos con algunos que se dicen de espafioles, son 295 , con 2374 personas" (I,205). Es notoria la proliferación de los ladinos en esta región; en el pueblo de Guaymoco, por ejemplo, éstos suman 710 personas en 147 familias, mientras que los indios comprenden 236 familias con 790 personas. Si los datos son correctos, resulta significativa la diferencia en la proporción entre el número de individuos por familia entre ambos grupos, que podría indicar diferencias socioeconómicas importantes: la familia media ladina es de 4.8, mientras que la de los indios es de 3.3.

El mismo Cortés da una clave para entender en parte esta situación demográfica, al sef̂alar que en esta provincia hay más ladinos que indios y que los primeros se han aduefado de las tierras fértiles, mientras que los indios viven en las tierras malas y quebradas, unos porque asf "apetecen vivir" y otros porque se esconden y huyen "a los montes por librarse de los perjuicios, engafios y robos con que los perjudican y aniquilan los ladinos" (I.150).

El mestizaje. La mezcla racial y social es para el arzobispo un motivo de constante preocupación, considerándola como la causa de la degradación del indio, aunque también como un medio para redimirlo. ${ }^{32}$

En su visita a Texuthla, en El Salvador, seffala la conveniencia de separar a indios de ladinos. Se sorprende de encontrar indios dociles y atentos, "de muy buen modo", de quienes "... tuvimos mucho gusto en haberlos visto y tratado". La razón, explica, es que de las 82 familias del pueblo, tan sólo una es ladina, por lo que no hay mezcla entre unos y otros. "La mezcla con los ladinos es fundamento poderoso para que sean los miserables indios ladrones, maliciosos, atrevidos y viciosos en toda especie de pecados".

32 Aunque considera perjudicial la mezcla en curso entre españoles, ladinos e indios, ve con entusiasmo la idea de separar a niñas de sus padres para volverlas honestas $e$ instruidas y luego casarlas con españoles (I,141). Véase las conclusiones mís adelante. 
$\mathrm{Y}$ eso porque los ladinos engañan, usurpan bienes y perjudican en todo sentido a los indios, particularmente en colaboracion con las autoridades, para "chuparles sus intereses" $(I, 211)$. Seffala que otro factor que influye en los de Texuthla es la presencia de cinco eclesísticos buenos y aplicados. Considera que es la falta de buenos eclesiásticos (espanfoles, por supuesto) la causa de que los indios conserven "sus idolatrias, supersticiones y abusos" (Ibid.).

Más adelante, el prelado critica duramente al sistema de repartimientos, que beneficia a los hacendados, a costa del beneficio público: “... cultívese en buena hora las haciendas, pero por medio de criados asalariados por todo el año y en los tiempos que se necesitan más operarios, precise la justicia a los ladinos que viven harto ociosos y no a los miserables indios ocupados en sus cultivos" (I,297). Con esto se evidencia que la explotación económica cra una razón poderosa para el mantenimiento de las distinciones "culturales".

Escandaliza al obispo la frecuencia y el ambiente de libertinaje y vicios con que se mezcla la gente entre sf. Al igual que en muchos otros lugares, en San Antonio Suchitepéquez, el informe del cura dice que el mayor vicio es la embriaguez, que los indios por lo regular se emborrachan con chicha, y otros con aguardiente que compran a los ladinos que lo fabrican. Pero además, "indios como ladinos van a verse a las riberas de los ríos" donde incurren en "deshonestidades", lo cual dice haber confirmado cuando al revisar los libros de administración, encontró que "la tercera parte son nifos bautizados de padres no conocidos". La corrupción de esa parroquia es tan grave, que en ella un eclesiástico tenfa 2 concubinas y 13 hijos, "tan sinvergüenza, que a ninguno se le ocultaba... y con este escándalo administraba los sacramentos y decía misa" (II,276).

La mezcla de la gente es para Cortés la causante de los mayores males para la sociedad. En la Presidencia de Santa Cruz del Chol se habla únicamente el castellano pero "nada puede saberse si son españoles, indios o ladinos, porque son una mezcla, desorden y confusión de todos": 
en un mismo trapiche viven de todas estas especies por iguales partes; los espafioles sumamente atrevidos, los indios igualmente temerosos, los ladinos disimulados y astutos; todos desnudos y juntos a todas horas del día y de la noche, sin Dios, sin Iglesia, $\sin$ Rey, sin vergüenza y sin honor (II,35).

También en el pueblo de El Tejar, Chimaltenango, es notoria la presencia de muchos ladinos. 193 familias de 481 indios contrastan con 26 familias de 224 ladinos. ${ }^{33}$ Además de la mala administración del párroco, "puede conjeturarse el desgraciado estado de esta parroquia, que con la mezcla de indios y ladinos hay noticia de hallarse en situación bien deplorable" (II,181). El pueblo de San Andrés Itzapa, vecino a El Tejar, reporta una población total de 4487 personas en 939 familias, 269 constituyen 57 familias de españoles y ladinos, aunque advierte el prelado que estos padrones son "muy defectuosos", al igual que en otras provincias. La misma situación parece ocurrir en San Martín Jilotepeque, donde también viven "algunos espaffoles y bastantes ladinos".

El caso del pueblo de Escuintla, con una población de 660 ladinos en 230 familias y 346 familias indias con 1254 personas. permite observar los tipos de relaciones entre unos y otros. En la descripción de dicha parroquia, el prelado observa que sus rfos son considerados "muy saludables para baños" y por esa razón el pueblo es muy visitado por gente de la capital en los meses de fró, lo cual deja a sus habitantes mucho dinero, pero también dichos baños se prestan, según el religioso, para todo tipo de deshonestidades, vicios y pecados. Al igual que en otras parroquias, preocupa al religioso la frecuencia de separaciones entre los conyuges y el amancebamiento, fomentados por las mismas leyes, por lo que considera que su "remedio es imposible en lo humano en viviendo juntos indios y ladinos". Al respecto, relata el caso de un indio de Cuyotenango, al que "habiéndole mandado que hiciera vida maridable con su mujer, me respondio que lo desea-

${ }^{33}$ Nótese la diferencia de la media familiar, de 2.5 a 8.6 . 
ba, pero que vivía en Escuinta amancebada con un ladino con algunos hijos y consintiéndolo sus padres" (II,242).

La parroquia de Don García, al oeste de Escuintla, ha sido prácticamente ocupada por los ladinos, desplanzando a los indios pipiles: "se ha hecho posesion de ladinos y mulatos, con algunas haciendas de espafioles, pero cuidadas por ellos y la mejor que vi y más útil es de un ladino" (II,246). Por otro lado, dice que la gente de estas tierras está perdida, porque "no sirven para curas ni aun para nada, porque habituados y viviendo siempre entre tantos monstruos de embriagueces, incestos, deshonestidades, aunque sean de buenas costumbres, tienen estas cosas por nifferfas y por tan generales, que sin ellas no puede vivirse" (II,248).

En ciertos pueblos del altiplano occidental que se encuentran muy aislados, las diferencias entre indios y ladinos es, a los ojos del prelado, menos marcada, siendo incluso semejantes unos y otros, debido a lo "cerrado" de los pueblos. Asf, en la parroquia de Cuilco, "los ladinos de estos pueblos son de las mismas inclinaciones que los indios; de la misma estolidez y costumbres, del mismo idioma y mezclados en matrimonio con ellos" (II,137-138). Sin embargo, observa que los ladinos "no pagan diezmo, ni primicia" ni se les puede hacer que cumplan con dichas obligaciones.

De los espafíles hacendados y sus relaciones con la poblacion indigena y ladina no se registra mucha información, pero sf de aquellos "que se dicen espafioles" y que viven junto a indios y ladinos en el campo, que sí son citados con más frecuencia. Dos referencias interesantes sobre los espafioles rurales, por la jerarquía social que all se expresa, son, una sobre el valle de Guastatoya, donde la población de las haciendas y trapiches "se compone de 62 espanfoles caballeros, de 49 espanfoles, de 317 mulatos y de 197 indios", y la otra es relativa al valle de Tocoy, que "se compone de 100 espanfoles caballeros, de 49 espafioles, de 623 mulatos y de 416 indios" (I,288).

Caso excepcional es el pueblo de San Raimundo, en Sacatepequez, que registra 74 familias espafiolas con 646 personas, superando a los 597 indios del mismo pucblo. En otros lugares, sin embar- 
go, no aparecen referencias especfficas a la población española. Por ejemplo en la parroquia de Mixco se reportan 8 haciendas y 1 ingenio sin detallar la composición de sus habitantes. De la vecina paroquia de la Asunción, donde hoy se encuentra la ciudad capital, sollo se dice que all las familias "Todas son mezcla y confusión de espaffoles, indios y ladinos".

Las referencias a la población de origen africano y a las llamadas castas son pocas. Quizá la más relevante sea la relacionada con la hacienda dominica de San Jerónimo, en la Presidencia de Salamá. Verapaz, donde se dice que "habrá más de mil personas y de ellas como setecientas son esclavas... Concibo ser esta hacienda la más preciosa del reino... hay esclavos que trabajan con perfeccion todo género de oficios necesarios...".

En fin, de los hechos narrados por el arzobispo, hay uno donde se revela con intensidad el carácter de las diferencias sociales, y que conjuga un asunto moral español, una identidad indigena y una condición ladina. Le ocurrió con los hombres del Ayuntamiento y los principales de Cuyotenango, al pedirles algunos nifos para educarlos y hacerlos curas. Aunque explico a los principales la nobleza de sus propositos, estos disculparon su negativa, llorando y argumentando que eso no era posible porque eran indios;

¿Qué importa, les decía, que seais indios?, antes por lo mismo estoy muy obligado a favoreceros... [pero] insistían, somos indios y hay niños ladinos que le darán tal vez. No, queridos míos, les replicaba, porque vosotros soís diferentes de los ladinos y también como nosotros buenos y a vuestros hijos los puedo acomodar y a los de los ladinos no (II,277-278).

No sólo consideran que no tienen el derecho a educarse y ser sacerdotes católicos, sino que tampoco lo quieren. Seffala el prelado a continuación que de todo el arzobispado sólo pudo conseguir un niffo, a pesar de haberles ofrecido a los padres hasta cinco tostones mensuales para ayudarlos por la falta del hijo. Los ladinos definitivamente no eran considerados sujetos de derecho, no pueden recibir ayuda, sus nif̃os no pueden ser acomodados por el ar- 
zobispo, son malos, no son objeto de salvación. Los espaffoles, en cambio, son buenos - y eso comparten con los indios- y tienen la obligación de ayudarlos.

\section{Conclusiones}

Así sucede al medio del siglo tercero de su conquista, así es de temer que sucederá siempre y hasta el fin... $(I, 11)$

Es evidente el peso de la religión y la moral en la visión de Cortés y Larraz. Para él, el problema fundamental de la diócesis era la ausencia de un cristianismo real. Los indios seguran adorando a sus dioses, vivían como animales, explotados y oprimidos. Los ladinos, aunque se decfan cristianos, eran ateos, corruptos y viciosos. Los espafíoles del pafs estaban muchos de ellos contaminados y corruptos por vivir entre los mágicos. De alli que sostenga como la única y verdadera solución al terrible estado de la diocesis la conversión al cristianismo. Los indios (y también los otros) tenfan que convertirse en verdaderos cristianos, vestirse y cubrir su desnudez, dejar de emborracharse y de pecar.

En este sentido, la propuesta del arzobispo es la aculturación, pues lo primero que debe cambiar es algo cultural, los indios deben ser cristianos y dejar de ser lo que son. Según el, una manera de lograrlo sería estableciendo colegios para nifos, sin trato con sus padres y con maestros competentes, "y en habiendo niñas honestas e instruidas casarlas con espanoles, pues por este medio se extinguirian las malas costumbres, lenguas y aun el nombre de indios" (I,141). Por eso critica al paganismo, antiespanfolismo, y falta de interes por el bienestar material de parte de los indios, aunque a veces elogie su honestidad, bondad ("porque vosotros sois diferentes de los ladinos y como nosotros buenos") y laboriosidad.

Pero también su crítica tiene un contenido sociológico, al afirmar que el término indio expresa una determinada condición social, es sinónimo de miseria, ignorancia, esclavitud y explotación. 
Dicho término solo desaparecerá cuando las personas que nombra dejen de ser oprimidas. ${ }^{34}$

Respecto a los ladinos, en cambio, manifiesta un claro desprecio y no parece ver en ellos más que una lacra y una maldición. deplorando su maligna influencia hacia los indios y acusándolos de ser la causa principal de la degeneración de la sociedad. Su aversión hacia estos no le permitió verlos de otra manera, como habria sido el considerar su precaria condición social, carencia de derechos jurídicos, su creciente importancia demográfica, y su propia dinámica social.

Los espafioles casi no aparecen en el discurso "etnológico" de Cortés, aunque de hecho están siempre presentes, se les puede ver entre lineas, ya que la visión del prelado reproduce en parte la ideologia del poder, al formular argumentos y justificaciones al servicio de la clase social dominante. De sus paisanos critica el afán explotador, su crueldad hacia los indios, el haberse alejado de la ley y la religion para vivir en el libertinaje, el mezclarse con la plebe y ser progenitores de las castas, de vagabundos y delincuentes.

¿Como era realmente la sociedad guatemalteca? Pienso que el informe de Cortés es sincero al reproducir opiniones y juicios que él considera correctos; lo es en tanto que su intención fue comunicar la verdad de los hechos observados a alguien de su propia cultura, a su magestad, el Rey. Por otro lado, fue sincera también su intención con respecto a los guatemaltecos, al escribir el informe convencido que de esa manera podría contribuir a la solución de sus grandes males. Que su descripción sea la verdad, es otro asunto. En gran medida los hechos descritos son factuales, son observaciones directas "en el terreno", de experiencias de vida, son veridicas.

Sin embargo, también es cierto que el marco de su visión religiosa y etnocéntrica influenció decididamente la información, impidiéndole pensar los hechos desde otra perspectiva menos estrecha y más

34 Ante la tiranía del alcalde mayor de Nebaj, el prelado afirma que ser indio significa vivir subordinado a todos, tiranizado y "sin remedio" (II, S0). 
tolerante. Sus constantes acusaciones de idolatrias, vicios y deshonestidades no le dejaron ver que eso mismo tambien expresaba otras realidades. Detrás de las "idolatrias" se escondia una profunda religiosidad y cultura indigenas, $y$ las "deshonestidades" y el mestizaje también hablan de relaciones afectivas y humanas entre la población.

En su obra, Cortes presenta una interpretación de la sociedad guatemalteca fundamentada en la distincion de categorfas culturales como español, indio, ladino, etc., aunque sin ignorar la determinante juridica arriba mencionada, que aparece como algo dado. Tal perspectiva "culturalista" la retoma de sus antecesores y de sus contemporáneos, asumiéndola como una realidad, como algo de sentido común.

En su concepción pueden distinguirse tres niveles de analisis: un nivel de generalidad que comprende a toda la población de la diocesis, donde se identifican rasgos propios de los chapines (aunque el no utiliza este término), de lo guatemalteco, de la cultura nacional, rasgos creados a lo largo de dos siglos y medio de vida en sociedad, como lo son la delimitación y administración territoriales, el sistema de gobiemo, la economfa, religión, costumbres, e incluso los vicios comunes a la generalidad de los habitantes. Un segundo nivel es la distinción de culturas, es decir, el de cada una de las grandes categorfas, en su especificidad y en su relación con las otras. ${ }^{35}$ Por último está un tercer nivel más concreto, que comprende al conjunto de rasgos particulares de un pueblo o parroquia, ${ }^{36}$ como son su lengua, creencias, costumbres, etc. y que correspondería grosso modo a lo que hoy se denomina etnia.

Las categorfas del segundo nivel ocupan en el analisis de Cortés un lugar central: las diferencias cualitativas están entre espaffoles, negros, indios y ladinos, mientras que las diferencias al interior de cada uno de estos grupos son secundarias. Para él, las distinciones

35 Ejemplos de esto son sus afirmaciones de que los ladinos son corruptos. o que los indios "todos son del mismo modo".

${ }^{36}$ A lo largo de la colonia también se empleo el término nación para referirse a un grupo indigena en términos de su especificidad lingüística y política. 
entre los indios no eran mayores que sus similitudes, y lo mismo puede decirse para los otros.

De lo anterior se desprende que una aplicación imprecisa del término etnia para el análisis de aquella sociedad colonial, lejos de aclarar la problemática puede obscurecerla. ${ }^{37}$ Un ejemplo de esto se observa en Macleod (op.cit.), quien se propone analizar las relaciones "étnicas" entre españoles e indios derivadas del sistema económico, en especial lo relativo a la explotación y extracción de riquezas en la producción (salario y migración laboral), el tributo y la derrama. Según el autor, este tipo de relaciones entre ambas "etnias" conducfan a la aculturación o ladinización de los indios. ${ }^{38}$ Tal concepción plantea un proceso histórico univoco y simplista, que contrasta con los datos de la Descripción, los cuales muestran por el contrario, la complejidad de las influencias culturales: los ladinos no eran sólo los indios aculturados, o mestizos, pues entre ellos habfa muchos "que se dicen espafioles", pero que son considerados ladinos, por vivir en valles y en pajuides. ${ }^{39}$ Cortés es claro en seffalar que la influencia cultural es mutua, que todos los grupos cambian al interactuar y mezclarse. Por ejemplo, los espaffoles ya no se espantan de las abominaciones de los mági$\cos$, al grado de afimar que "son también indios los que se dicen espanfoles nacidos en América en orden a vivir, según lo que se dice costumbres" (II,119), y en el caso de los indios, la adopción de elementos ajenos, como los nuevos cultivos o la crianza de animales, no conlleva necesariamente una pérdida de su cultura. El mismo ejemplo de Macleod sobre el impuesto personal cobrado exclusivamente a $\operatorname{los}$ indios ${ }^{40}$ sugiere que el tributo, más que aculturar, servía para diferenciar a los indios del resto de la población.

37 El no distinguir estos niveles de etnicidad, puede conducir a tratar como iguales la confrontación cultural entre indígenas y europeos, con los conflictos entre pipiles y ladinos del suroriente de la díccesis, por ejemplo.

38 Esta posición teórica corresponde a la corriente culturalista norteamericana. Cf. Jos6 Alejos García, "Los mayas: discurso y realidad". Estudios de Cultura Maya, vol. XVIII (1991) pp. 487.502.

39. Véase al respecto el caso de la parroquia de Mita.

${ }^{40}$ Macleod, op. cit., p. 9. 
¿Qué era Guatemala en aquella época? En parte, era como la describe el prelado: era un paif, un Reyno, una colonia espanfola en América. Él la observa como el arzobispado, como la diócesis que le correspondfa administrar. Es claro que en su informe quedan sin considerar aspectos muy importantes de esa sociedad, pero que se pueden inferir. A veces las anécdotas del arzobispo permiten entrever los grandes abismos al interior de la sociedad, como aquella de la noticia de una epidemia de sarampión, en que los médicos de la ciudad de Goathemala acordaron una receta destinada a los pueblos por medio de los alcaldes mayores, en la cual se ordenaban medicinas para controlar la enfermedad. Comenta el prelado con ironía que en los pueblos no existen ni médicos ni boticas y que además, los indios no tomarian tales medicinas, "sino las de sus temascales y otras que acostumbran" (II,61). El hecho es revelador, pues muestra el profundo desconocimiento de las clases dominantes acerca de la sociedad en que viven.

Es claro que no se trata de una nación, o de un conjunto de naciones, en el sentido modemo del término, aunque sí puede hablarse de la persistencia de nacionalidades indigenas.

Algunos datos permiten entrever que esa sociedad, con todo y lo anárquico y anómalo que el proceso pudo ser, empezaba a gestar formas de identidad social propias. Existe ya una masa de habitantes de la diocesis que comparten los mismos "vicios": los pajuides están poblados por gente de todos lados, que se juntan entre sf y se dan cita en los ríos; los velorios y las sarabandas eran ocasiones donde todos se mezclaban, habfa frecuentes invitaciones formales a fiestas de un pueblo a otro, a donde concurrian a los juegos "principalmente ladinos y españoles", a bailar y emborracharse sin medida, asunto que los mismos curas ven con indiferencia $(\mathbf{I}, 135)$. Existen además elementos religiosos generalizados en buena parte del reino, como lo es el culto al cristo de Esquipulas. que para el 15 de enero atrafa en romería a cerca de 20 mil personas $(1,261,265)$.

Más de 200 años han pasado desde la visita de Cortés y Larraz al interior de Guatemala; su sociedad ha seguido cursos ya presa- 
giados o delineados en aquel entonces: las relaciones, muchas de ellas conflictivas, entre indios y ladinos se han intensificado. Unos más que otros han ido quedado cada vez más inmersos y subordinados a la cultura de Occidente, en virtud del sistema de dominación español, y más tarde en beneficio de otros europeos.

En todo caso, la interacción continua y cada vez más profunda entre los distintos grupos al interior, fue creando un tejido social complejo y dinámico, que conformó lo que hoy son las repúblicas o naciones neocoloniales, siempre dependientes y sujetas a un control económico, político y cultural extranjero. Guatemala es hoy una nación violenta y enajenada que carga con todos los defectos y todos los dafíos heredados de aquel pasado, pero es, con todo, una sociedad, constituida historicamente, con derecho a ser libre, a superarse y a forjar su propio destino.

\section{BIBLIOGRAFIA}

Alejos Garch, Jost, "Los mayas: discurso y realidad", Estudios de Cultura Maya, Vol. XVIII, 1991.

Bricker, VictoriA, The Indian Christ, the Indian King, Texas, Austin University Press, 1981.

Contrerns, Daniel, Una rebelión indigena en el Partido de Totonicapán, Guatemala, Universidad de San Carlos, 1968.

Cortes y Larraz, Pedro, Descripción geográfico-moral de la Diócesis de Goathemala, Adrián Recinos (editor), Guatemala, Sociedad de Geografía e Historia, Biblioteca "Goathemala", vol, XX, 1958, 2 tomos.

Garcta Añoveros, Jesús Marta, Población y estado sociorreligioso de la diocesis de Guatemala en el último tercio del siglo XVIII, Guatemala, Editorial Universitaria, USAC, 1987.

Macleod, Murdo, Relaciones étnicas y la sociedad indigena en la Provincia de Guatemala, ca. 1620-ca.1800, Guatemala, SISG, 1987

Martinez Peliez, Severo, La patria del criollo, Guatemala, Editorial Universitaria, USAC, 1970.

Ximenez, Francisco, Historia de la Provincia de San Vicente de Chiapa $y$ de Guatemala, Guatemala, Sociedad de Geografía e Historia, 1930, tomo II, p. 10. 